\title{
ARBEJDERKLASSENS SITUATION OG DEN STATSLIGE KRISEPOLITIK
}

Allan Andreassen og Tyge Kjær

\section{Indledning}

Formålet med artiklen er at belyse virkningerne af de såkaldte kriseindgreb og andre dele af den statslige $\varnothing$ konomiske politik siden krisens begyndelse i 1974/75. Virkningerne gøres op i to retninger: dels kriseindgrebenes virkninger på reproduktionsomkostningerne for henholdsvis den beskæftigede og den ubeskæftigede del af arbejderklassen, og dels indgrebenes virkninger på totalprofitmassens størrelse, d.v.s. kriseindgrebenes virkninger på den samfundsmæssige udbytningsgrad og på beskæftigelsen af produktive arbejdere.

Siden krisegennemslaget har de siddende regeringer hævdet, at formålet med deres $\varnothing$ konomiske politik har været at forbedre betalingsbalancen og gennem denne forbedring at nedbringe arbejdsløsheden. De anvendte midler har været ændringer i skatten, besparelser på de offentlige budgetter, fors $\emptyset \mathrm{g}$ på lønindgreb og stigende tilskud til erhvervslivet.

Kriseårenes skatte- og socialpolitik, statslige indgreb og »henstillinger « til de generelle overenskomstforhandlinger kan meget vel få det til at se ud som om, at lønningerne og dermed levevilkårene er politisk bestemt. Det kan se ud som om det er Folketinget, som fastsætter levevilkårene - direkte gennem indkomstpolitik, og indirekte gennem beskatning og socialpolitik, m.v. Det kan se ud som om, at den nominelle lønstigning, som staten ikke kan hindre gennem indkomstpolitikken, kan den opsuge gennem beskatningen og/eller hente tilbage gennem de sociale nedskæringer. 
Det forholder sig imidlertid ikke så simpelt. Det vil føre til forkerte slutninger, hvis arbejdslønnens bevægelser og reproduktionsomkostningernes udvikling alene bliver forstået som resultater af statslig eller parlamentarisk magtudfoldelse. ${ }^{1}$ Den statslige krisepolitiks materielle forudsætninger og virkninger er mere kompliceret, men også mere snedig end som så.

Til forståelsen af statspolitikken må man inddrage de materielle forhold, som går forud og som danner grundlaget for de forskellige dele af den statslige krisepolitik og for disse politikkers virkninger. I denne sammenhæng er det vigtigt at fastholde den borgerlige stats klassemæssige placering og objektive funktion i det kapitalistiske samfund.

I det borgerlige samfund fremtræder klasserelationerne eller udbytningsrelationerne ikke direkte; de fremstår derimod som prisrelationer, hvorigennem den samfundsmæssige rigdom fordeles via kategorierne løn, profit og skat. Disse prisrelationer og fordelingskategorier skjuler den samfundsmæssige rigdoms oprindelse, udvisker klasserelationerne og frister til en forståelse af staten og den statslige krisepolitik som størrelser, der er hævet over klasseforholdene eller udbytningsforholdene og som kan sætte sig ud over det kapitalistiske samfunds objektive bevægelseslove. Men sådan forholder det sig ikke i virkeligheden; den borgerlige stat er en integreret del af det kapitalistiske samfund; dens eksistens forudsætter udbytning og dens funktioner er knyttet til sikring af udbytningsforholdene.

I artiklens første del belyser vi disse problemstillinger nærmere ved at unders $\varnothing$ ge statens $\varnothing$ konomiske grundlag. Vi skal unders $\emptyset$ ge, hvorfra skatten stammer, d.v.s undersøge forholdet mellem løn, profit og skat. Formålet hermed er at vise det materielle grundlag for den statslige krisepolitik. Krisepolitikkens dominerende indhold har været størrelse og fordeling af statens indtægter (skatterne) og statens udgifter. Derfor er beskatningens former og størrelse af afgørende betydning for forståelse af såvel statslig krisepolitik som arbejderklassens almene situation.

I artiklens anden del behandler vi krisepolitikkens udvikling fra krisegennemslaget frem til det seneste forlig i foråret 1980. Formålet med dette afsnit er ikke at give en detaljeoversigt over samtlige indgreb, men derimod at påvise

1. I Løn, pris og profit advarer Marx generelt mod den type af betragtninger, som kritiseres her; sammenfattende siger han: »Hvis I behandler kampen om lønstigninger uafhængig af alle disse omstændigheder [d.v.s. uafhængig af kapitalens forudgående aktioner] og kun ser på forandringerne i lønnen og overser alle de andre forudsætninger, som de udspringer af, så går I ud fra falske forudsætninger og må komme til falske følgeslutninger. Marx \& Engels: Udvalgte skrifter, bd. I, Kbh. 1952, s. 436. Jvf. også her fremstilling og kritik af den politiske løn som reformismens $1 \varnothing n t e o r i$ hos Bredsdorff, Brinch, Hansen: Arbejderklassen og kapitalismen; Kurasje nr. 21, s. 54-62. 
hovedtræk og udviklingstendenser i krisepolitikken. Den statslige krisepolitik er til syvende og sidst et spørgsmål om at ændre delingsforholdet mellem løn og profit, d.v.s mindske arbejderklassens reproduktionsniveau og forøge den samfundsmæssige profitmasse. Selvom der er en vis ensartethed i krisepolitikken fra forlig til forlig, mener vi at kunne påvise et udviklingsforløb i krisepolitikken. Den begynder som en politik rettet mod arbejderklassens beskæftigede del; efterhånden rettes den mere og mere mod arbejderklassens svage led: de ubeskæftigede med tydelige forhåbninger om, at man herigennem kan fremtvinge lønnedgange for den beskæftigede del af arbejderklassen, og derved forøge udbytningsgraden.

For at lette forståelsen af det efterfølgende skal vi kort nævne nogle forudsætninger for vores undersøgelse. Arbejderklassen er delt i to dele: den beskæftigede og den ubeskæftigede del. Den beskæftigede del reproduceres gennem lønarbejdet, og den ubeskæftigede del reproduceres stort set gennem statspenge (understøttelse af forskellig art). Den beskæftigede del er igen del i to dele: den produktive og den uproduktive del. Produktiv arbejder er den, hvis arbejdskraft anvendes på en sådan måde, at merarbejdet, d.v.s. arbejdsdagens ubetalte del, kan opsuges og forvandles til profit. Af statistiske grunde er vi afskåret fra at undersøge hele befolkningen og dens fordeling på henholdsvis produktivt og uproduktivt lønarbejde. Vores unders $\varnothing$ gelse bygger derfor ikke på totalstørrelser, men på gennemsnitsbetragtninger. Det empiriske grundlag er den industrielle gennemsnitsarbejder, industriarbejdernes gennemsnitlige udbytningsforhold, beskatningsforhold, m.v., som vi antager er et gyldigt udtryk for de forhold, der gælder for den produktive totalarbejder.

I artiklen anvendes udtrykket »stat « og »statsapparat « i bred betydning. Hvis det ikke direkte af sammenhængen fremgår noget andet, så menes der hermed både stat, amter og kommuner. Når det drejer sig om oprindelsen af statens $\varnothing$ konomiske grundlag og om hovedtrækkene i skatte- eller profitfondets anvendelse er der nemlig ingen væsentlig forskel mellem stat amt og kommune.

\section{Løn, profit og skat}

Kommune-, amts- og statsskatten stammer som bekendt i hovedsagen fra to former for beskatning, nemlig indkomstbeskatningen og varebeskatningen, 
eller direkte og indirekte skatter. ${ }^{2}$ Tabel 1 viser de beskatningsformer, som kommune-, amts- og statsskatten inddrives igennem.

\section{Tabel 1. Samtlige skatter og afgifter i mia. kr. for årene 1970-77. Anført i 1977-priser.}

\begin{tabular}{|c|c|c|c|c|c|c|c|c|}
\hline & 1970 & 1971 & 1972 & 1973 & 1974 & 1975 & 1976 & 1977 \\
\hline Indkomstskatter: & 46 & 55 & 58 & 64 & 69 & 62 & 66 & 65 \\
\hline $\begin{array}{l}\text { Indirekte skatter } \\
\text { (afgifter): }\end{array}$ & 34 & 36 & 39 & 40 & 36 & 36 & 41 & 43 \\
\hline $\begin{array}{l}\text { Skat af formue, ejen- } \\
\text { dom og besiddelser: }\end{array}$ & 6 & 7 & 7 & 7 & 7 & 7 & 7 & 8 \\
\hline Ialt: & 86 & 98 & 106 & 111 & 112 & 105 & 114 & 116 \\
\hline
\end{tabular}

Kilde: Statistisk tiårs oversigt 1979; Kbh. 1979. For at gøre tallene sammenlignelige er 1970-76 tallene opregnet i 1977-priser på basis af forbrugerprisindekset. Beløbene er afrundet, så de stemmer med totalsummen. Opgørelsen er excl. bidrag til sociale ordninger (ATP, mv.), som i perioden svinger mellem 2-4 mia. kr.

Fra såvel de almene bestemmelser af det kapitalistiske samfund som fra hverdagen kender vi størrelserne løn og profit, som er de fremherskende fordelingsformer, svarende til samfundets to hovedklasser. ${ }^{3}$ Hvor hører skatten hjemme i denne sammenhæng?

For at kunne behandle dette spørgsmål må vi undersøge to problemstillinger hver for sig. Det ene problem er skattens oprindelse og distribution til statsapparatet. Det andet problem er statsapparatets anvendelse af disse midler. Sammenblandes disse to problemstillinger, ender man i vilkårlige og moralske bestemmelser af forholdet mellem løn, profit og skat.

2. Indkomstskatten, lignet efter en progressiv skala, blev indført ved skattelovene i 1903. Skat på varer, besiddelser, o.s.v. har i forskellige former eksisteret længe før kapitalismen. Vareskatterne var typisk punktskatter på et afgrænset vareudvalg. I 1962 indførtes en generel omsætningsafgift (engrosomsen); i 1967 erstattedes den af merværdiafgiften (momsen). Indtræden i EF førte til ophævelse af en række punktafgifter. På grund heraf og på grund af den stadig stigende momsprocent (fra $10 \%$ til $22 \%$ i dag) er resultatet blevet, at hovedparten af de indirekte skatter stammer fra vareskatten momsen.

3. Det vil sige kapitalistklassen og arbejderklassen, som her - hvor det drejer sig om løn og profit - kan afgrænses til den produktive kapitalist og den produktive arbejder. Disse to klassefraktioner er ikke talmæssigt dominerende, men dominerende i den forstand, at det er herfra - d.v.s. fra forholdet mellem disse to klasser (kapitalforholdet) - alle væsentlige samfundsmæssige forhold udspringer. 


\subsection{Skattens oprindelse og distribution til statsapparatet}

Forholdet mellem løn, profit og skat kan i hovedprincippet opstilles som én af to muligheder:

- er skatten en del af arbejdslønnen og en del af profitten, som henholdsvis arbejderklassen og kapitalistklassen efter fælles, stiltiende overenskomst overlader til staten for at sikre de sider af reproduktionen, som den enkelte arbejder og den enkelte kapitalist ikke kan sikre gennem et direkte varek $\varnothing b^{4}$

- eller er skatten - både varebeskatningen og indkomstbeskatningen - en form for distribution af mervardi; d.v.s. er skatterne den form, hvorigennem staten eksproprierer en del af merværdien.

Den sidstnævnte er den grundliggende og principielle bestemmelse af skattens oprindelse; ikke mindst fordi den første betragtningsmåde begrunder skattens oprindelse med dens anvendelse, og dermed sammenblander problemstillingerne. I de teoretiske diskussioner er forståelsen af skat som merværdi da også den mest udbredte opfattelse, som vi kort skal begrunde nærmere. ${ }^{5}$

For at forklare sammenhængene skal vi tage udgangspunkt i den umiddelbare produktionsproces og dens værdimæssige elementer: værdien af arbejdskraft og produktionsmidlerne og merværdien. Vi behandler her kun de to hovedbeskatningsformer: vareskat og indkomstskat.

Ved varebeskatningen fremtræder skattens oprindelse fra merværdien mest direkte. Vi tager derfor udgangspunkt her; siden behandler vi indkomstbeskatningen. Historisk kommer iøvrigt varebeskatningen før end indkomstbeskatningen; den sidstnævnte stammer som almen beskatningsform fra skattereformen i begyndelsen af dette århundrede, medens varebeskatningen endog findes lang tid før end den danske kapitalisme udvikler sig.

4. Denne opfattelse kunne karakteriseres som en kontingentopfattelse. Hver samfundsborger betaler et kontingent, hvorom der i en lidt ældre bog om skatter blomstrende hedder: »... I visse foreninger opstår på den måde adskillelsen mellem aktive og passive medlemmer. Og pengebidraget kan være gradueret efter vedkommendes alder, $\varnothing$ konomiske evne, o.s.v. Under samme synsvinkel er det rimeligt at betragte de mangeartede »kontingenter «, som hver enkelt borger må yde til de store »foreninger «, hvoraf han alene i kraft af sin bostavn er tvunget medlem: stat og kommune. Disse ydelser er hans betaling for det gode, det er at leve i et ordnet retssamfund «. H. Gammelgaard: Stats- og kommuneindtægternes historiske udvikling; s. 307 i: E. Marstrand, m.fl. (red): Den Danske Stat; Kbh. 1940, s. 307-322.

5. Jvf. Jens Henning Rasmussen: Skatterne - Til en politøkonomisk bestemmelse af statsapparatet; i: Kurasje nr. 12, s. 81-95. Vi bygger i en vis udstrækning på denne artikel i dette afsnit; artiklen må dog kritiseres for placeringen af varebeskatningen og vareskatterne i forhold til arbejdskraftens værdi; de indirekte, men ikke de direkte skatter regnes med under arbejdskraftens værdi, hvad der ikke er konsekvent i forhold til artiklens hovedsynspunkter. 
Varebeskatningen: Umiddelbart ser det ud som om en vareskat (punktskatter såvel som generelle vareskatter) blot stammer fra en nominel forhøjelse af prisen på varerne ud over varens værdi. Varebesidderen - kapitalisten - sælger øjensynlig varen over dens værdi, d.v.s. prisen må forhøjes med det beløb, som statsapparatet indkasserer.

Blev vi stående ved denne forklaring, ville det betyde, at vi hævdede, at der gennem beskatningen skabes værdi i cirkulationen, d.v.s. skatten måtte stamme fra statslige fif og optrækkeri i cirkulationen; det kan ikke lade sig gøre. ${ }^{6}$ Med den anførte forklaring havde vi endnu ikke anvist den kilde, som varebeskatningen stammer fra. Produktion af værdi finder kun sted i produktionsprocessen, og er afsluttet hermed. Vareskatten må derfor have sin oprindelse i produktionen, hvorfra den værdidel må stamme, som tilflyder staten i form af vareskatten.

Vi kan anskue sagen fra den produktive kapitals synsvinkel. Kapitalisten køber arbejdskraft og produktionsmidler som betingelse for sin produktion. Vareskatten - i dette tilfælde som skat på de købte produktionsmidler - optræder for kapitalisten som et nødvendigt kapitaludlæg på linie med udlægget til selve produktionsmidlerne. Vareskatten optræder som kapitalindskud; men hvorfra betales den. Af den producerede merværdi. Med de indkøbte varer producerer kapitalisten en given vareværdi, som består af følgende dele: værdien af den anvendte arbejdskraft og produktionsmidler og merværdi. I tilfælde af en skat på de varer, han indkøber til produktionen, betaler han et ekstraudlæg, som modsvarende formindsker den del af merværdien, som han kan realisere som profit. Heraf følger, at vareskatten kun er mulig ved, at den produktive kapitalist deler en del af merværdien med statsapparatet. Iøvrigt i lighed med den del af merværdien, han deler med handelskapitalisten og eventuelt med den rentebærende kapital. Vareskatten stammer derfor fra den del af merværdien, som statsapparatet kan tiltvinge sig i kraft af sin samfundsmæssigt set suveræne magt. ${ }^{7}$

6. Det ville være et brud på værdiloven at hævde det, og dermed et brud på den kendsgerning, at værdi er udtryk for den samfundsmæssige, gennemsnitlige arbejdstid, der må tilsættes varen for dets fremstilling; en vare bliver som bekendt hverken fremstillet ved cirkulation eller ved beskatning.

7. Ved momsen (merværdiafgiften) gør der sig særlige forhold gældende; den er en særlig form for vareskat. Ved $k \varnothing b$ af produktionsmidler betaler kapitalisten varen og en afgift. Ved salget af de forarbejdede varer, som nu værdimæssigt er forøget med værdien af det tilsatte arbejde, betales påny en afgift, som nu må modregnes den først betalte afgift. Momsen fungerer derfor som en afgift på den i den pågældende produktion tilsatte værdi. (Skattens navn: moms/ merværdiafgift er derfor ikke dækkende; den er en afgift af hele den tilsatte værdi, ikke blot merværdien). Den omstændighed, at momsen fungerer som en afgift på den tilsatte værdi, ændrer imidlertid intet ved vareskattens oprindelse. Den har stadig sin oprindelse i den del af 
Beskattede varer indgår såvel i den produktive konsum som i den individuelle konsum. Man kunne nu hævde, at den vareskat, som indgår i konsummidlerne, må arbejderen betale af sin løn, og derfor må den del af vareskatten, som stammer fra konsumcirkulationen, have sin oprindelse i arbejdskraftens værdi. Det er imidlertid ikke tilfældet; selv den skat vil have sin oprindelse i merværdien. På dette punkt er problemstillingen identisk med indkomstskattens oprindelse; den skal derfor behandles nedenfor.

Indkomstbeskatningen: der er tre typer af indkomstskat, nemlig indkomstskat af kapitalrevenuer, selskabsskat og indkomstskat af lønarbejderindkomster. De to første er størrelsesmæssig af mindre betydning (ca. 10\%) og teoretisk set indlysende: denne skat må nødvendigvis have sin oprindelse i merværdien, fordi selskabsprofitten og kapitalrevenuerne har det. Hvorfra stammer så indkomstskatten af lønarbejderindkomster.

Det er her vigtigt at fastholde, hvad der overhovedet skal forstås med $a r$ bejdskraftens vardi.

Ligesom enhver anden vare er arbejdskraftens værdi bestemt af den arbejdsmængde, som dens fremstilling kræver. Der må bruges en bestemt mængde livsfornødenheder af et menneske, for at hun/han kan opretholde livet. Arbejdskraftens værdi vil derfor være bestemt af den mængde arbejde, der medgår til produktionen af den nødvendige mængde livsfornødenheder.

Arbejdskraftens værdi er en historisk fikseret størrelse; dens minimum er bestemt af den rent fysiske grænse for det minimum af livsfornødenheder, som arbejderen kan opretholde livet med. Kapitalisten prøver til stadighed at trykke lønnen ned til dens fysiske minimum, medens arbejderen udøver et tryk i den modsatte retning. Hovedbetingelserne for det tryk, som arbejderklassen samlet kan udøve, er at finde i den industrielle reservearmé og dens størrelse; det skal imidlertid ikke behandles nærmere her. ${ }^{8}$

Uanset den aktuelle størrelse af arbejdskraftens værdi er det vigtigste i denne sammenhæng, at arbejdskraftens værdi altid oplфser sig $i$ vaerdien af de varer, som stofligt danner grundlaget for arbejderens reproduktion.

Indkomstskatten er ikke varek $ø$ b. Indkomstskatten indgår ikke i værdien af livsfornødenhederne. Det samme gælder konsumvareskatten. For den betalte skat får arbejderen ikke en direkte materiel modydelse i form af livsfornødenheder. Skattebetalingen er ikke udtryk for køb - salg; ingen lige værdier byt-

merværdien, som kapitalisten giver afkald på til statsapparatet, men skatten beregnes på en anden måde, sammenlignet med f.eks. punktskatterne. Det er hele forskellen.

8. Vi vender i en vis udstrækning tilbage til problemet. Vedrørende reservearméens løntrykkende virkninger i den nuværende krise skal vi henvise til Allan Andreassen, Søren Kerndrup og Tyge Kjar: Lønsystemer i krisen; Kurasje nr. 19/20, s. 47-93. 
tes. Skattebetalingen er derimod at forstå som ekspropriation, og som sådan indgår den ikke $\mathrm{i}$ arbejdskraftens værdi.

Men indkomstskatten og konsumvareskatten indgår $i$ arbejdslønnen. Det er åbenbart. Det betyder, at arbejdskraftens værdi ikke er sammenfaldende med, men mindre end arbejdslønnen eller den variable kapital. Hvor stammer forskellen fra.

Vi skal påny anskue sagen fra den produktive kapitals synsvinkel. Kapitalisten køber arbejdskraft og produktionsmidler. Ved betaling af arbejdskraften må han dels præstere et kapitaludlæg svarende til arbejdskraftens værdi og dels et udlæg, svarende til indkomstskatten og konsumvareskatten. Hans variable kapital består altså af arbejdskraftens værdi og et værditillæg. I lighed med argumentationen for vareskatten kan denne ekstra værdidel kun stamme fra merværdien. Ligeledes i lighed med vareskatten på produktionsmidlerne formindsker det den del af merværdien, som han kan realisere som profit. Disse skatter optræder derfor som en forhøjelse af kostprisen, og en modsvarende sænkning i enkeltkapitalens profit.

Forskellen mellem vareskatten og indkomstskatten er minimal. Vareskatten på produktionsmidler fungerer for kapitalisten som et forøget kapitalinds$k u d$, vareskatten på konsumvarer og indkomstskatten fungerer for kapitalisten som en forøget revenu-udgift, ${ }^{9} \mathrm{i}$ begge tilfælde formindsker de hans andel af profitten, og i begge tilfælde fungerer de som distributionsformer af merværdi til statsapparatet.

Sammenfattende: Vi har søgt at vise, at skatten uanset beskatningsform principielt stammer fra merværdien. Og dermed at disse beskatningsformer fungerer som distributionsformer af merværdi til statsapparatet. Sagen kan betragtes fra en anden og måske mere simpel synsvinkel, nemlig som et spørgsmål om, hvordan den samlede arbejdsdag er fordelt. Hvor stor en del af arbejdsdagen går til arbejderens reproduktion, hvor stor en del af arbejdsdagen distribueres til statsapparatet som skat, og hvor stor en del af arbejdsdagen tilfalder kapitalisten som profit. Et udtryk for fordelingsforholdene fremgår af figur 1 på næste side.

Denne oversigt over udbytningsforholdene, som kun må tages som en illustration, gør det fristende at sige, at det korte af det lange er, at arbejderen er dobbelt udbyttet: dels udbyttet af kapitalen og dels af staten. Intet kunne vare mere forkert, når vi som her taler om den egentlige udbytning af arbejderklassen.

9. Jvf. Karl Marx: Resultater af den umiddelbare produktionsproces, Århus 1974, s. 116, hvor det hedder: »Forvandles f.eks. samtlige indirekte skatter til direkte, så betales skatterne nu som før, men udgør ikke længere kapitalindskud, men revenuudgift. Muligheden for denne formforvandling viser sin yderlighed, ligegyldighed og tilfældighed i forhold til den kapitalistiske produktionsproces.« 
Figur 1. Arbejdsdagens fordeling (udtrykt i priser) for industriens arbejdere og funktionærer, under forudsætning af gennemsnitlig beskatning. Tallenes fordeling er fra 1977.

Arbejdsdagens deling (udtrykt i priser)

Nominel løn = variabel kapital Indistriel protit:

\begin{tabular}{|c|c|c|c|}
\hline Udbetalt løn & & Direkte skat & Indinstriel profit \\
\hline Disponibel løn & Afgifter & Direkte skat & lndustriel prosit \\
\hline Reel arbejdsløn & \multicolumn{2}{|c|}{ 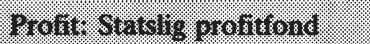 } & industriel profit \\
\hline
\end{tabular}

Prismæssigt udtryk for

Prismæssigt udtryk for arbejdskraftens værdi merarbejdets værdi

Kilde: Forholdet mellem nominal løn og industriel profit er baseret på lønkvoten, jvf. beregningerne i Industriel udvikling, TEK/SAM-RUC 1979. Skattens andel er baseret på gennemsnitlige skattetryksprocenter efter egne beregninger, jvf. senere. Den industrielle profitmasse er inklusiv den del af profitten, som industrikapitalen eventuelt deler med den rentebærende kapital, men den er eksklusiv den del af profitten, som industrikapitalen deler med handelskapitalen. Profitmassen er derfor større end angivet på figuren, svarende til den handelskapitalistiske profitmasse.

Forudsætningen for distributionen af merværdi til statsapparatet er, at udbytningen har fundet sted; det sker og kan kun ske i den umiddelbare produktionsproces. Statsapparatets ekspropriation af en del af merværdien ændrer intet ved de grundlæggende klasseforhold, ved forholdet mellem kapital og arbejde, eller ved arbejdsdagens deling i en nødvendig del og en merarbejdsdel.

Den statslige beslaglæggelse af en del af udbytningsresultatet bringer staten i et modsætningsforhold til kapitalen om merværdiens deling. Men samtidig danner stat og kapital en fælles front overfor arbejderklassen, fordi det er fra den, udbytningsresultatet stammer.

Modsætningsforholdet mellem stat og kapital har visse ligheder med de enkelte kapitalers indbyrdes modsætningsforhold i konkurrencen om totalprofitmassens deling. Sålænge alt er godt, d.v.s. så længe udbytningsgraden vokser, eksisterer der et praktisk »broderskab «; så snart krisen bryder frem og 
formindsker den merværdi, der er til deling, skærpes på den ene side modsætningsforholdet mellem kapital og stat, og på den anden side den fælles front overfor arbejderklassen.

Statsapparatets mulighed for at sætte sig på en del af udbytningsresultatet har som historisk forudsætning, at udbytningsgraden har nået en vis størrelse, som igen hænger sammen med det omfang, hvormed kapitalen behersker den samlede produktionsmåde. Under akkumulationsbetingelser, hvor udbytningsgraden vokser - d.v.s. under den intensive kapitalakkumulation, vil statsapparatet have de største muligheder for at $\varnothing$ ge beskatningen uden at bringe sig i et modsætningsforhold til kapitalen. Vi kan illustrere disse sammenhænge ved at vise udviklingen i fordelingen af gennemsnitsarbejderens arbejdsdag (udtrykt i priser) på egen reproduktion og på den profitmasse, som henholdsvis statsapparatet og kapitalen suger op.

Tabel 2. Udvikling i udbytningsgrad og den gennemsnitlige arbejdsdags deling i en betalt del (disponibel arbejdsløn) og en ubetalt del, bestående af henholdsvis statslig profitfond og industriel profitfond. Industriens arbejdere og funktionærer, treårs perioder 1960-77.

\begin{tabular}{lcccccc}
\hline & $1960-62$ & $63-65$ & $66-68$ & $69-71$ & $72-74$ & $75-77$ \\
\hline $\begin{array}{l}\text { Udbytningsgrad i \%: } \\
\text { Arbejdsdag fordelt på: }\end{array}$ & 180 & 226 & 217 & 262 & 292 & 234 \\
- arbejder: & 36 & 31 & 32 & 28 & 25 & 30 \\
- statsapparat: & 24 & 30 & 30 & 34 & 42 & 39 \\
- kapital: & 40 & 39 & 38 & 38 & 33 & 31 \\
- ialt: & 100 & 100 & 100 & 100 & 100 & 100 \\
\hline
\end{tabular}

Kilde: Egne beregninger på basis af Industristatistikken, diverse årgange. Udbytningsgraden er beregnet som forholdet mellem disponibel arbejdsløn og den profitmasse, som gennemsnitsarbejderen producerer. Profitmassen er beregnet som industriel profitmasse pr. industriens arbejdere og funktionærer + profitmasse, som distribueres til statsapparatet pr. arbejder og funktionær; (funktionærerne er medtaget, fordi hovedparten af dem må opfattes som produktive). Den sidstnævnte størrelse er beregnet under forudsætning om gennemsnitlig skattetryksprocent (jvf. note $10 \mathrm{og}$ forbeholdene i anmærkningerne til figur 1). Udfra de samme størrelser er arbejdsdagens fordeling beregnet.

Tabellen viser, at udbytningsgraden vokser gennem 1960'erne og i begyndelsen af 1970'erne, dog med en nedgang i 1966-68 og 1975-77, som vi vender tilbage til i kriseafsnittet. Den stigende udbytningsgrad hænger sammen med den intensive kapitalakkumulations relative merværdiproduktionsmetoder, 
som har ført til en sænkning i arbejdskraftens værdi, altså til en reduktion i arbejdsdagens betalte del. En udbytningsgrad på $180 \%$ betyder, at den produktive arbejder skal arbejde 1,8 time for de fremmed for hver time, han arbejder for sin egen reproduktion. Udbytningsgraden er øget med mere end $60 \%$ frem til begyndelsen af 1970'erne, hvor hver produktiv arbejder skal arbejde 2,9 time for de fremmede for hver time, han arbejder for sin egen reproduktion.

Den stigende udbytningsgrad danner gennem 1960'erne og i begyndelsen af 1970'erne frem til krisen grundlag for en forøgelse af den del af arbejdsdagen, der distribueres som skat til statsapparatet. Dens andel af arbejdsdagen vokser da også i perioden fra $24 \%$ til $42 \%$.

Umiddelbart kunne det se ud som om staten henter sin stigende andel af arbejdsdagen på bekostning af arbejderen, idet hans andel falder fra $36 \%$ til $25 \%$ i samme periode. Men det ville være en ombytning af årsag og virkning. Såvel statsapparatets stigende andel som arbejderens faldende andel af arbejdsdagen har sin forudsatning $i$ den stigende udbytningsgrad, som er frembragt af udviklingen i den umiddelbare produktionsproces. Det har også følgende konsekvens: hvis ikke en stigende del af arbejdsdagen var distribueret til statsapparatet som skat, så ville den være tilfaldet kapitalen som profit.

Disse betragtninger gælder for de mere langsigtede udviklingssammenhænge. Den mere langsigtede udvikling i beskatningens størrelse er et spørgsmål om merværdiens delingsforhold mellem stat og kapital. De anførte sammenhænge udelukker imidlertid ikke, at statsapparatet midlertidig kan sænke og hæve udbytningsgraden. Det skal vi behandle i det efterfølgende.

\subsection{Oprindelig og sekundær udbytning}

Den merværdi, som distribueres til statsapparatet, bliver i stigende omfang distribueret via arbejdslønnen, som det fremgår af tabel 1. Det sammen med en stigende beskatning i det hele taget betyder en stadig stigende forskel mellem arbejdsløn og disponibel arbejdsløn - eller mellem variabel kapital og arbejdskraftens værdi. Udviklingen siden 1950 kan illustreres med figur $2 .{ }^{10}$

10. Tallene i figur 2 og i den efterfølgende tabel 3 er baseret på materiale fra Statistisk Tiårs Oversigt, diverse årgange, og er beregnet på følgende måde: først beregnes en gennemsnitlig skattetryksprocent, dernæst udregnes der en fordeling mellem skat og disponibel arbejdsløn på basis af gennemsnitsarbejdslønnen, som er vist i figur 2; skattetryksprocenterne står i tabel 3. Beregninger af denne type er ikke uden problemer, som kort skal nævnes her, og som må medtages i fortolkningerne af resultaterne. (noten fortsætter på næste side). 
Figur 2. Gennemsnitsarbejdslønnen for en arbejder i industrien, og skatternes andel heraf. 1955-arbejdslønnen $=100$.

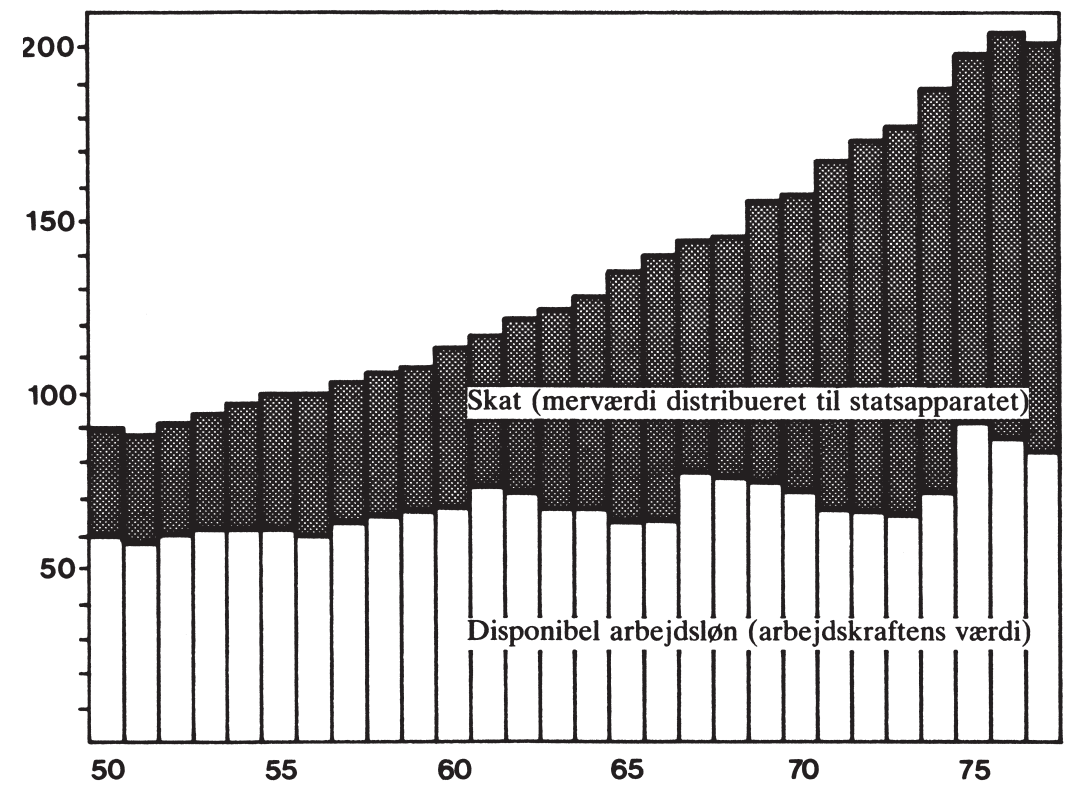

Kilde: Den gennemsnitlige arbejdsløn er beregnet på basis af Industristatistikkens oplysninger, som derefter er deflateret med forbrugerprisindekset og sat på indeks, $1955=100$. Denne størrelse er dernæst opdelt på skat og disponibel arbejdsløn efter beregningsangivelserne i note 10 .

Skattetryksprocenten beregnes på basis af den samlede skattepligtige indkomst og samtlige indkomstskatter og afgifter. Der er naturligvis et gennemsnit, som næppe gælder for de mindste eller for de største indkomster; den er for høj for dem begge; for de mindste indtægter er den for høj på grund af den skattefrie bundgrænse og den progressive beskatning: for de største indtægter er den for høj på grund af fradragssystemet. Men man kan vel nok gå ud fra, at de mellemindkomster, som vi her behandler, $i$ det mindste beskattes efter gennemsnitstallene. For det første fordi den progressive beskatning er forsvindende; indkomstskatter til amt og kommune og afgifter betales ikke progressivt stigende efter indkomsten; det gælder kun for den statslige indkomstskat, som udgør en mindre del af den samlede beskatning. For det andet på grund af fradragssystemet, som bygger på et såkaldt skatteevneprincip, som i virkeligheden betyder lempelig beskatning af kapitalrevenuer og af meget store lønindtægter, idet skatteevneprincippet i virkeligheden er et fradragsevneprincip.

Skattetryksprocenterne, som er beregnet på basis af skattepligtig indkomst, bruges dernæst til at udregne den disponible arbejdsløn. Det sker på basis af den gennemsnitlige arbejdsløn, altså bruttolønnen. Det kan give fejl, som dog er begrænset, fordi skattefradraget for mellemindkomsterne er små, og fordi den reelle skattetryksprocent for disse indkomster nok er højere end gennemsnittet.

Bortset fra disse beregningsmæssige vanskeligheder, så må figur 2 anses for at være sigende, når det drejer sig om at belyse den stigende forskel mellem arbejdslønnen og disponibel arbejdsløn. 
Figuren viser, at den deflaterede gennemsnitsarbejdsløn er fordobbelt over perioden, medens det prismæssige udtryk for arbejdskraftens værdi (disponibel arbejdsløn) stort set er konstant over perioden med nogle karakteristiske svingninger, som vi siden skal vende tilbage til i detalje.

En del af disse svingninger hænger sammen med det, der kunne kaldes for de sekundare udbytningsformer, som er at opfatte som tillægsudbytning i cirkulationen. ${ }^{11}$ Den gør sig gældende i den almindelige varehandel, men også for beskatningen i den udstrækning den er formidlet over arbejdslønnen.

Hæves eller sænkes beskatningen pludselig, vil det umiddelbart få betydning for den mængde varer, som den enkelte arbejder kan købe til sin reproduktion, fordi en større eller mindre del af arbejdslønnen distribueres til statsapparatet. Stiger f.eks. beskatningen vil det svare til, at arbejdskraften sælges under dens normale værdi; udbytningsgraden vil vokse, men kun i den udstrækning og kun så længe det ikke lykkes arbejderklassen gennem et modsat rettet tryk at hæve arbejdslønnen, svarende til at arbejdskraften påny sælges til sin værdi. Den sekundære udbytning gennem beskatningen kan forstås som modifikationer eller svingninger i forhold til den oprindelige udbytning, og er overhovedet forbundet med arbejdslønnen som distributionsform af merværdi til statsapparatet. ${ }^{12}$

I krisen i 1966/67 og ved den nuværende krises gennemslag blev beskatningen sænket betydeligt (i henholdsvis 1967 og 1975; se tabel 3). Disse skattesænkninger skulle principielt betyde, at den industrielle profitmasse for$\emptyset$ ges i samme omfang som formindskelsen i den statslige profitmasse. Det er imidlertid ikke tilfældet i fuld omfang, fordi hovedparten af det statslige profitfond distribueres over arbejdslønnen. Af figur 2 fremgår det, at den disponible arbejdsløn forøges i de pågældende år. Det kan karakteriseres som den omvendte sekundare udbytning. Skattesænkningen betyder imidlertid ikke, at der på længere sigt sker en højnelse af arbejdskraftens værdi, som det da også fremgår af figuren for de efterfølgende års udvikling.

11. Jvf. Karl Marx: Kapitalen; Kbh. 1972, bd. 3:3, s. 793, hvor den sekundære udbytning karakteriseres som en udbytning, som forløber ved siden af den oprindelige, nemlig ved siden af den som foregår umiddelbart i selve produktionsprocessen.

12. Forudsætning for sekundær udbytning gennem beskatning er, at arbejderklassen ikke umiddelbart kan få kompensationer for stigende beskatning, f.eks. gennem dyrtidsregulering. I 1963 gennemførtes der en ændring af den automatiske dyrtidsregulering, hvorefter direkte og indirekte skatter skulle holdes udenfor lønreguleringspristallet, angiveligt med det formål at effektivisere finanspolitikken, d.v.s. den politik, som går på at regulere ‘ $\varnothing$ konomien' gennem skatte- og afgiftspolitik og det offentliges udgiftspolitik. Jvf. Sv. Å. Hansen: Økonomisk vækst i Danmark, Kbh. 1974, bd. II, s. 183-84, s. 193. 
Tabel 3. Gennemsnitlige beskatningsprocenter. Indkomstskatter og afgifter i procenter af skattepligtig indkomst de respektive år.

\begin{tabular}{lllllllllll}
\hline & 1960 & 1961 & 1962 & 1963 & 1964 & 1965 & 1966 & 1967 & 1968 \\
\hline Direkte skatter: & 21,7 & 20,3 & 20,4 & 23,5 & 25,4 & 29,9 & 28,7 & 25,4 & 24,4 \\
Indirekte skatter: & 18,9 & 18,0 & 20,6 & 22,1 & 22,9 & 23,7 & 25,9 & 19,8 & 21,6 \\
Skatteprocent ialt: & 40,6 & 38,3 & 41,0 & 45,6 & 48,3 & 53,6 & 54,6 & 45,2 & 46,0 \\
\hline
\end{tabular}

$196919701971 \quad 197219731974197519761977$

$\begin{array}{llllllllll}\text { Direkte skatter: } \quad 27,7 & 30,9 & 35,6 & 36,9 & 38,7 & 40,0 & 33,7 & 34,5 & 33,8\end{array}$

$\begin{array}{llllllllll}\text { Indirekte skatter: } \quad 23,3 & 23,9 & 23,8 & 24,7 & 24,0 & 21,6 & 20,4 & 22,5 & 23,9\end{array}$

$\begin{array}{llllllllll}\text { Skatteprocent ialt: } \quad 51,0 & 54,8 & 59,4 & 61,6 & 62,7 & 61,6 & 54,1 & 57,0 & 57,7\end{array}$

Kilde: Egne beregninger på basis af de respektive årgange af Statistisk tiårs oversigt. Den skattepligtige indkomst i 1969 er anslået. Vedrørende beregningsforudsætninger henvises der til note 10 .

Det skyldes dels, at beskatningen påny øges, men også - og det er det vigtige i denne sammenhæng - at den industrielle reservearmé, som den almindelige regulator af arbejdskraftens værdi, fremtvinger et fald i den variable kapital, altså i arbejdslønnen, svarende til den mindskede beskatning.

Fordi skatten har sin oprindelse i merværdien, og fordi fordeling af denne merværdi mellem kapital og stat i hovedsagen sker over arbejdslønnen, betyder det, at en pludselig ændring i beskatningen får umiddelbare konsekvenser for arbejderklassens reproduktionsniveau, altsammen som følge af den sekundære udbytning, men ingenlunde sådan, at beskatningens størrelse regulerer arbejdskraftens værdi, kun svingninger omkring den.

\subsection{Anvendelsen af det statslige profitfond.}

De midler, som statsapparatet råder over er som bekendt ikke identisk med de inddrevne skatter. Midlerne kan forøges ved statslån, statskreditter, m.v. De seneste års udvikling fremgår af tabel 4. 
Tabel 4. Forøgelse af stat, amter og kommuners gæld, indenlandsk og udenlandsk, samt samtlige skatter og afgifter for årene 1970-77. Anført i 1977-priser.

\section{$\begin{array}{llllllll}1970 & 1971 & 1972 & 1973 & 1974 & 1975 & 1976 & 1977\end{array}$}

Statsapparatets for-

$\emptyset$ gelse af gælden:

Skatter og afgifter:

$\begin{array}{rrrrrrrr}0 & -4 & -1 & -5 & -7 & +2 & +14 & +11 \\ 96 & 98 & 106 & 111 & 112 & 105 & 114 & 116\end{array}$

Kilde: Egne beregninger på basis af Statistisk tiårs oversigt. 1978. Opgørelsen er excl. amters og kommuners gæld til staten. Den samlede gæld er opregnet i 1977-priser, hvorefter stigningerne er udregnet. Samlet gæld var i 1970 ialt på 31 mia. kr. I 1977 var den på 41 mia. kr., altsammen i 1977-priser.

Kriseårenes gældsforøgelse skyldes udelukkende stigende statsgæld, hvor hovedparten er optagelse af udenlandslån og udstedelse af statsobligationer.

Med de distribuerede (og lånte) midler deltager statsapparatet i den samfundsmæssige reproduktion. Dels købes de materielle bestanddele, hvormed statsapparatet deltager i den samfundsmæssige reproduktion - købet omfatter som bekendt både arbejdskraft og vareprodukter (produktionsmidler). Og dels distribueres statsmidlerne uden k $\varnothing b$, d.v.s. som tilskud og understøttelse (de såkaldte overførsler til personer og erhverv). Man kan få

Tabel 5. Statsapparatets samlede udgifter i 1979, fordelt efter anvendelsesform. I mill. kroner og procentvis fordelt.

Udgifter mill. kr.: $\quad$ i procent:

Driftsudgifter:

110.736

$55 \%$

Anlægsudgifter:

19.191

$10 \%$

Overførsler til personer:

55.810

$28 \%$

Overførsler til erhverv:

8.040

$4 \%$

Andre overførsler:

5.755

$3 \%$

Samlede udgifter:

199.536

$100 \%$

Kilde: Egen opstilling på basis af bilag 3 i Budgetredegørelse 1980, Kbh. 1980, s. 251-285. Andre overførsler omfatter udlån og overførsler til udlandet, og er i hovedsagen at opfatte som erhvervstilskud (overførsler til erhverv). 
et billede af, hvordan statsapparatet indgår i den samfundsmæssige reproduktion ved at se på de samlede udgifters fordeling efter anvendelsen, jvf. tabel 5 på foregående side.

Drifts- og anlag sudgifter. Statsapparatet køber arbejdskraft og forskelligartede produktionsmidler, som denne arbejdskraft anvender. Disse materielle bestanddele, hvormed staten deltager i den samfundsmæssige reproduktion, anvendes uproduktivt. ${ }^{13}$ Det betyder, at de indk $\varnothing$ bte produktionsmidler ikke fungerer som kapital og den indkøbte arbejdskraft ikke anvendes som merværdiproducerende. Om et arbejde er produktivt eller ej har intet at gøre med arbejdets indhold; arbejde med det samme materielle indhold kan være produktivt eller uproduktivt. Den omstændighed, at de fleste statsaktiviteter er tjenesteydelser, er derfor ikke årsagen til, at det statslige arbejde er uproduktivt. Arbejdets uproduktive karakter skyldes derimod, at det specifikke forhold mellem arbejde og kapital, som karakteriserer den kapitalistiske produktion, ikke er til stede; det statslige arbejde er ikke bytteværdisættende arbejde. Produktivt arbejde er i modsætning hertil det arbejde, som anvendes på en sådan måde, at produktionsmidlerne bliver midler til opsugning af ubetalt arbejde; kort og godt: arbejde som anvendes kapitalistisk.

Selvom det statslige arbejde i hovedsagen er uproduktivt, så er der alligevel tale om lønarbejde. Værdien af den uproduktive lønarbejders arbejdskraft er bestemt på samme måde som for den produktive, nemlig som værdien af de varer, som danner det stoflige grundlag for reproduktionen.

I konkurrencen med kapitalen må staten betale den samme eller tilnærmelsesvis den samme arbejdsløn for den arbejdskraft, den køber, som kapitalen. Da den arbejdsløn, som staten betaler, stammer fra det statslige profitfond, og da den beskattes i samme omfang, så vender den del af arbejdslønnen tilbage til statsapparatet, der ligger udover det, der modsvarer arbejdskraftens sædvanlige værdi. På den måde deler de statslige lønarbejdere vilkår med lønarbejderne i den umiddelbare produktionsproces. Også for dem virker reservear-

13. Det er klart, at den arbejdskraft, som statsapparatet anvender til administration, undervisning, m.v. anvendes uproduktivt. Det samme gælder imidlertid også den arbejdskraft, der anvendes ved statsvirksomhederne. Ved uproduktivt arbejde betales - som ved det produktive arbejde - kun en del af arbejdsdagen. Det uproduktive arbejdes ubetalte del cirkulerer imidlertid ikke; det materialiserer sig i produkter og tjenester, men det sælges ikke, fordi det uproduktive arbejde anvendes under betingelser, som gør dette arbejde til ikke-bytteværdisættende arbejde. Vedrørende den nærmere argumentation herfor henvises til Tyge Kjar: Om stat og statsfunktioner og de almene materielle produktionsbetingelser; TEK/ SAM-Grundkursus, 1979/80, bd. II, s. 7 ff (især s. 26-36). 
méen som den almindelige regulator af arbejdskraftens værdi. Den tidligere omtalte sekundære udbytning gennem vekslende beskatning virker på samme måde for statsapparatets lønarbejdere.

Men beskatningen af den statslige lønarbejder har et andet indhold og en anden oprindelse. Da staten udbetaler hele arbejdslønnen, men kræver en del tilbage i skat, betyder det, at værdierne blot bevæger sig frem og tilbage i forhold til det statslige profitfond.

Statsapparatets drifts- og anlægsudgifter betegnes ofte som 'kollektiv forbrug', men det er en ideologisk og upræcis angivelse af de formål, som de pågældende statsudgifter anvendes til. Mere end 60\% af driftsog anlægsudgifterne anvendes til sikring af de almene cirkulations- og udbytningsbetingelser, sikring af de almene og specifikke produktionsbetingelser samt sikring af de nødvendige arbejdskraftkvalifikationer; eller kort og godt: sikring af de kapitalistiske produktionsbetingelser. Af de resterende drifts- og anlægsudgifter anvendes langt den overvejende del til formål, som skal sikre reproduktionen af den ikke-beskæftigede del af befolkningen; kun en meget lille del af statsudgifterne indgår i hele befolkningens reproduktion og kan karakteriseres som 'kollektiv forbrug'.

Den omstændighed, at de statslige udgifter anvendes uproduktivt, og at statsapparatet beslaglægger en stigende mængde arbejdskraft, betyder, at en stigende del af den samfundsmæssige arbejdstid anvendes som ikke-merværdiproducerende arbejde, d.v.s. som arbejde, der ikke indgår i det særlige arbejde-kapitalforhold, og derfor ikke forgylder sin herre med ubetalt arbejde.

Af den samlede arbejdsstyrke på ca. 2,6 mill. personer svarede statsapparatets beskæftigelse til ca. 590.000 heltidsansatte; ${ }^{14}$ (antallet af beskæftigede personer er således højere, da deltidsbeskæftigelse forekommer i et ikke uvæsentligt omfang). Statsapparatet er en så dominerende arbejdsgiver, at den statslige arbejdsgiverpolitik har betydning for lønog arbejdsforhold i den umiddelbare produktionsproces.

Selvom statsapparatets vækst i form af flere lønarbejdere - især i begyndelsen af 1970'erne - har skærpet konkurrencen mellem stat og kapital om den forhåndenværende arbejdskraft, så er dette ikke udtryk for en grundlæggende modsætning mellem stat og kapital, idet den stigende uproduktive anvendelse af den samlede arbejdstid ikke sker på trods af den intensive kapitalakkumulation. Den er derimod et resultat af den kapitalistiske udviklings konsekvenser for den samlede samfundsmæssige reproduktion. Arbejdsmiljøforholdenes

14. Jvf. Budgetredegфrelse 1980, Kbh. 1980, bilag 4, s. 287-293. Den årlige vækst i statsapparatets ansatte var omkring 1970 på 7-8\%; ved krisegennemslaget faldt væksten til 2-3\%, steg derefter påny til optil 6\%; de seneste år er væksten påny reduceret til ca. $2 \%$. 
udvikling kan nævnes som eksempel. Den stadig forringelse af arbejdsmiljøet gennem 1960'erne og 1970'erne er tydeligvis forbundet med udviklingen af udbytningsformerne i produktionen. Konsekvenserne væltes over på statsapparatet. Det skønnes, at de ringe arbejdsmiljøforhold i dag koster statsapparatet ca. 16 mia. kr. årligt.

Overførsler til personer og erhverv. Vi skal ikke her nærmere behandle overførsler til erhverv; sammenhængen er ukompliceret: en del af den statsligt eksproprierede profitmasse sendes tilbage til kapitalerne som akkumulationsfond. Tabel 5 angiver, at der overføres ca. 8 mia. kr.; heraf er knap 75\% EF-landbrugsstøtteordninger; en række industristøtteordninger er ikke opf $\varnothing r t$ under »overførsler til erhverv«, men under driftsudgifter og andre overførsler. $\mathrm{Vi}$ vender tilbage til problemstillingen.

Tabel 6. Overførsler til personer i 1979, fordelt efter persongruppe. I mill. kroner og relativt fordelt.

\begin{tabular}{lrr}
\hline & $\begin{array}{c}\text { Udgifter } \\
\text { mill. kr.: }\end{array}$ & i procent: \\
\hline Pension (folke-, enke- og & & \\
$\quad$ efterløn): & 19.018 & 9,5 \\
Arbejdsløshedsunderstøttelse: & 11.415 & 5,7 \\
Invalidepension: & 6.736 & 3,4 \\
Dagpenge under sygdom, & & \\
$\quad$ øødsel og ulykkestilfælde: & 4.801 & 2,4 \\
Kontanthjælp: & 3.149 & 1,6 \\
Børnetilskud: & 2.727 & 1,4 \\
Uddannelsesstøtte: & 1.944 & 1,0 \\
Boligstøtte: & 1.236 & 0,6 \\
Andet: & 4.784 & 2,4 \\
Overførsler ialt: & 55.810 & 28,0 \\
Samlede statsudgifter: & 199.540 & 100,0 \\
\hline
\end{tabular}

Kilde: Egen opstilling på basis af bilag 3 i Budgetredegørelse 1980, Kbh. 1980, s. 251-285. Under Andet hører især tjenestemandspensioner, m.v.

Overførsler til personer drejer sig i hovedsagen om den del af befolkningen, som ikke reproduceres gennem lønarbejdet; d.v.s. personer, som ikke er i 
stand til at sælge deres arbejdskraft, enten fordi de er syge, for unge eller for gamle, eller på grund af arbejdsløshed. Overførslernes fordeling kan ses i tabel 6 på foregående side.

Som det fremgår af tabellen anvendes stort set alle overførslerne til reproduktion af den del af befolkningen, som fra et kapitalistisk standpunkt er at opfatte som overskudsbefolkning. ${ }^{15}$ Reproduktion af overskudsbefolkningen er gennem den historiske udvikling her i landet blevet et statsanliggende. For det første betyder denne statsligg ørelse, at en del af befolkningen reproduceres udenfor lønarbejde-kapitalforholdet, idet staten eksproprierer en del af profitmassen, og distribuerer den til den ubeskæftigede del af befolkningen. For det andet baner statsliggørelsen på forskellig måde vej for en $\emptyset$ get udbytning af arbejderen i den umiddelbare produktionsproces, idet den udgør et indirekte angrebspunkt mod arbejderklassens beskæftigede del gennem den statslige krisepolitiks sociale nedskæringer. Det vender vi tilbage til senere.

Vi skal afslutte dette afsnit om det statslige profitfonds anvendelse med nogle generelle betragtninger vedrørende statsudgifternes historiske nødvendighed.

Til forståelse af statsudgifternes og det statslige (uproduktive) arbejdes nødvendighed må man nødvendigvis tage udgangspunkt $i$ den umiddelbare produktionsproces.

Betragtes den umiddelbare produktionsproces snævert, så vil enhver statsudgift være overflødig. I fabrikken produceres der uden hjælp fra militæret, retsvæsnet, sundhedsvæsnet, skolevæsnet, o.s.v. Statsudgifterne fremstår fra denne synsvinkel som produktionens faux frais (falske omkostninger), hvor statsudgifterne blot vil være et fradrag af den producerede merværdi. Den form, hvorunder det sker, og den anvendelse, der gøres af statsudgifterne, vil fra den snævre betragtning være uden betydning.

Enhver produktion er imidlertid ikke blot produktion, men også reproduktion af forholdene selv. Gennem produktionen fremstilles de efterfølgende produktionsbetingelser, som ikke blot består i fremstilling af nødvendige materielle produkter, men også i reproduktion af de specifikke sociale forhold, som danner forudsætning for den fortsatte materielle produktion.

15. Kun børnetilskud og boligstøtte tilfalder også den beskæftigede del af befolkningen. Den del af børnetilskud og boligstøtte, som tildeles den beskæftigede del af befolkningen, indgår i denne befolkningsdels reproduktionsniveau, og derfor i arbejdskraftens værdi. Men fordi der er tale om små beløb, jvf. tabel 5 , ændrer det intet ved den tidligere anførte principielle betragtning, hvor det forudsættes, at arbejdskraftens værdi alene udtrykkes gennem den disponible arbejdsløn. 
For den kapitalistiske produktions vedkommende viser historien, at den proces, hvorigennem kapitalen i stigende omfang underlægger sig produktionen, samtidig udspalter områder, som kapitalen ikke reproducerer eller genfremstiller som betingelse for fortsat kapitalistiske produktion. I den udstrækning den kapitalistiske produktion ikke samtidig er reproduktion af de nødvendige produktionsbetingelser, så væltes opgaverne over på en instans, som står uden for produktionen: den borgerlige stat. Hermed bliver statsudgifterne nødvendige. Staten må ekspropriere en del af den samfundsmæssige arbejdstid for at reproducere de områder, som kapitalen ikke formår. Det, der fra et snævert synspunkt fremtrådte som produktionens falske omkostninger, forvandles til nфdvendige omkostninger. Historisk kan det ses ved, hvordan statsfunktionerne opstår og udvikles snævert forbundet med den kapitalistiske produktions udvikling. Det er imidlertid en længere historie, som vi ikke skal behandle her.

Det samlede statslige profitfond kan i overensstemmelse med de forskellige statsfunktioner - ses som fordelt over en række fonde, der på forskellig vis tjener til den samfundsmæssige reproduktion. De vigtigste kan opstilles således efter deres funktionsfelt:

- opretholdelse af de almene cirkulations- og udbytningsbetingelser, d.v.s. retsvæsen, politi, militær, m.v. Dette sker alene gennem køb af de materielle bestanddele, som indgår heri (arbejdskraft, materiel og bygninger, m.v.).

- sikring af de almene og specifikke produktionsbetingelser, de såkaldte erhvervsøkonomiske foranstaltninger, m.v. Dette sker i hovedsagen enten som tilskud, der retter sig mod konkurrencens konsekvenser for forskellige produktioner, eller i form af $\mathrm{k} ø \mathrm{~b}$ af de materielle bestanddele, som anvendes til etablering af de materielle produktionsbetingelser (infrastruktur) og de almene produktionsbetingelser (tilvejebringelse og fordeling af arbejdskraft).

- reproduktion af den del af befolkningen, som ikke reproduceres gennem lønarbejdet. D.v.s. arbejdsløshedsunderstøttelse, forskellige former for sikringsydelser, hospitaler, m.v. Både som tilskud og køb af de materielle bestanddele, som indgår i denne reproduktion.

- sikring af de kvalifikationer, som er nødvendige for henholdsvis den umiddelbare produktions arbejdskrafter som for cirkulationens og for statsapparatets arbejdskrafter. I hovedsagen som $\mathrm{k} \varnothing \mathrm{b}$ af materielle bestanddele (arbejdskraft, materiel, bygninger, mv.).

- tillægsreproduktion, d.v.s. statslige foranstaltninger, som retter sig mod såvel den beskæftigede som den ubeskæftigede del af befolkningen, og hvor statsapparatets udgifter indgår i den samlede reproduktion af befolkningen, 
såsom: rekreative og kulturelle tjenester, individuel sundhedstjeneste, m.v. Midlerne anvendes både til køb af de materielle bestanddele som til tilskud. ${ }^{16}$

Sammenfattende kan siges, at langt den overvejende del af statsudgifterne anvendes enten til fremskaffelse af materielle produktions- og reproduktionsbetingelser eller til reproduktion af den nødvendige arbejdsstyrke, materielt og åndeligt (kvalifikationsmæssigt).

De sidstnævnte reproduktionsforanstaltninger er dobbeltbundne. Det kan ikke nægtes, at de er til aktuel gavn for arbejderklassen; men det fjerner ikke deres kapitalistiske nødvendighed og afhængighed. Tag eksemplet med pensionsalderen. I 1922 blev alderen fastsat til 65 år; i 1937 blev der givet mulighed for pension ved 60 år med det formål at omfordele arbejdsløsheden. I 1946 blev disse muligheder fjernet, og i 1956 blev pensionsalderen hævet til 67 år, med mulighed for førtidspensionering ved 60 år. I 1977 blev førtidspensionsalderen nedsat til 55 år. I 1979 blev der etableret en efterlønsordning for de 60-66 årige for at fremskynde de ældres afgang fra arbejdsmarkedet.

Det viser, at der mellem kapitalakkumulationsfaserne og pensionsalderen er en nøje sammenhæng, som selvfølgelig - når akkumulationsbetingelserne er der efter, ligefrem kan give kapitalismen et »menneskeligt ansigt«.

\section{Krisen og krisepolitikken}

De statslige kriseindgreb siden 1974/75 må forstås udfra dels krisens historiske karakter og dels de grundtræk ved statens $\varnothing$ konomiske grundlag, som vi har påvist i det foregående.

Den omstændighed, at det statslige profitfond i hovedsagen distribueres til statsapparatet via lønformen har en afgørende betydning for, hvordan forholdet mellem stat og kapital udvikler sig under krisen. Det har med andre ord afgørende betydning for på den ene side, hvordan stat og kapitals ord fælles front mod arbejderklassen udvikler sig, d.v.s. spørgsmålet om forøgelse af

16. Statsudgifternes fordeling på de forskellige områder kan være vanskeligt at opgøre præcist, men følgende procentvise fordeling af udgifterne kan dog give et indtryk af størrelsesforholdene. Opgørelsen er baseret på 1979-statsudgifterne, jvf. Budgetredegørelse 1980, Kbh. 1980: $16 \%$ til almene cirkulations- og udbytningsbetingelser. $12 \%$ til almene og specifikke produktionsbetingelser. $46 \%$ til reproduktion af den ikkebeskæftigede del af befolkningen. $19 \%$ til sikring af kvalifikationer. Og $7 \%$ til tillægsreproduktionen. 
udbytningsgraden; og på den anden side hvordan den indbyrdes front mellem stat og kapital udvikler sig, d.v.s. spørgsmålet om profitmassens deling mellem kapital og stat.

Den statslige krisepolitik kan imidlertid ikke gennemsættes uafhængig af de lovmæssigheder, som gælder for den kapitalistiske produktions kriseforløb. Vi skal derfor indlede med en kort karakteristik af den nuværende krises kapitalistiske karakter.

\subsection{Den nuværende krises grundtræk}

Årsagen til den nuværende krise er som bekendt overakkumulation. Den anlagte kapital er vokset hurtigere end den totale profitmasse, som har betydet en faldende profitrate; det har fremkaldt krisen.

Den samfundsmæssige profitmasses størrelse er bestemt af antallet af produktive arbejdere og af udbytningsgraden, hvor udbytningsgraden er forholdet mellem arbejdsdagens ubetalte og betalte del. Da antallet af produktivt beskæftigede stort set er uændret op til krisegennemslaget, fremkommer krisen ved, at udbytningsgraden ikke er vokset i samme omfang som den anlagte kapital, som igen hænger sammen med kapitalakkumulationsforløbets virkninger på den umiddelbare produktionsproces især i begyndelsen af 1970 'erne. ${ }^{17}$

Med tabel 2 har vi tidligere vist, at statsapparatet gennem 1960'erne og begyndelsen af 1970'erne har beslaglagt en stigende del af arbejdsdagens ubetalte del. Derfor kunne man hævde - og det er blevet hævdet - at kriseårsagen snarere er, at statsapparatet ved at ekspropriere en stigende del af profitmassen har berøvet den produktive kapital dens profit, og derfor fremkaldt krise. Det er imidlertid en forkert betragtningsmåde, som sniger sig uden om det væsentlige i årsagen til krisen - helt på linie med påstande om, at den rentebærende kapitals stigende andel af profitmassen er en selvstændig kriseårsag.

Gik vi forudsætningsvis ud fra, at staten f $\phi r$ krisen havde eksproprieret en mindre del af totalprofitmassen, ville det have haft to konsekvenser: for det første ville statsapparatet med de mindskede statsmidler have bidraget i mindre omfang til etablering af de forskelligartede produktionsbetingelser; det var

17. Vi skal ikke her nærmere behandle sammenhængen mellem det forudgående akkumulationsforløb og den nuværende krise og forskellen mellem den intensive kapitalakkumulations kriser og den nuværende krise, men henvise til Allan Andreassen \& Tyge Kjar: Krisen og venstrefløjens handlemuligheder; i Kurasje nr. 21, s. 157-186, især s. 172-185. 
i større omfang forblevet opgaver for kapitalen, som ville have beslaglagt en del af den forøgede profitmasse, som var til rådighed for den produktive kapital. For det andet ville den produktive kapitals akkumulationsfond have været større. Det ville gennem 1960'erne og 1970'erne have forceret den intensive kapitalakkumulation, men ikke have ændret på denne akkumulationsforms uundgåelige resultat: overakkumulation.

Det er nemlig ikke profitmassens absolutte størrelse, som er afgørende for krisegennemslaget, men derimod forholdet mellem akkumulationsform og udbytningsforhold. Hvis der akkumuleres intensivt, så skal udbytningsgraden vokse hurtigere end kapitalakkumulationen, hvis profitraten ikke på et eller andet tidspunkt skal falde. Et andet fordelingsforhold mellem kapital og stat under den intensive akkumulationsperiode ville måske have haft betydning for krisegennemslagets karakter, men ikke for krisegennemslagets uundgåelighed. ${ }^{18}$

Krisegennemslaget virker selvforstærkende på krisen, idet gennemslaget betyder braklægning af kapital og ophør af kapitalakkumulation. Beskæftigelsen af produktive arbejdere falder. Den totale profitmasse falder i samme omfang som beskæftigelsen. Det kan belyses med figur 3 på næste side. ${ }^{19}$

Figuren viser, at krisegennemslaget betyder et fald i den industrielle kapitals profitmasse på ca. $15 \%$. Faldet i profitmassen kan kapitalen modgå på to måder i forhold til den umiddelbare produktionsproces: enten kan beskæftigelsen af produktive arbejdere forøges, det forudsætter kvantitative udvidelser i den kapitalistiske produktion; eller udbytningsgraden kan bringes til at stige

18. Det, der er det uundgåelige, er, at kapitalen gennem udviklingen af det samfundsmæssige arbejdes produktivkraft indsnævrer sit eget grundlag: forholdet mellem den akkumulerede rigdom og antal af produktive arbejdere. Deraf kriserne. Og derfor udgør kapitalismen et miserabelt grundlag for den fortsatte udvikling af arbejdets produktivkraft. Jvf. afsnittet »Overskydende kapital og overskydende befolkning « (incl. »Tilføjelser«), i Karl Marx: Kapitalen, bd. 3:2, s. 333-350.

19. Det er vigtigt at gøre klart, hvad fremstillingen i figur 3 af den industrielle profitmasses størrelse viser. Problemet opstår, fordi der er tale om absolutte størrelser. Den viser, hvor stor en profitmasse, den industrielle produktion realiserer. Principielt kunne faldet i profitmassen hidrøre fra ændrede fordelingsrelationer i forhold til stat og handelskapital, samt fra forringede realiseringsbetingelser i forhold til verdensmarkedet. Den omstændighed, at profitmassen udviser samme pludselige fald som beskæftigelsen, sandsynligg ør, at det er herfra langt den overvejende del af faldet stammer. Relevant statistik er kun tilgængeligt fra industristatistikken. Vi opfatter imidlertid den industrielle arbejder som et gyldigt udtryk for den produktive totalarbejder, og industriens udviklingsforhold som et rimeligt udtryk for den samlede kapitalistiske produktion; om ikke andet, så fordi den industrielle produktion er den dominerende. 
Figur 3. Profitmasse og beskæftigelse (arbejdere og funktionærer) for den industrielle totalkapital i perioden 1973-1977. Indeks.

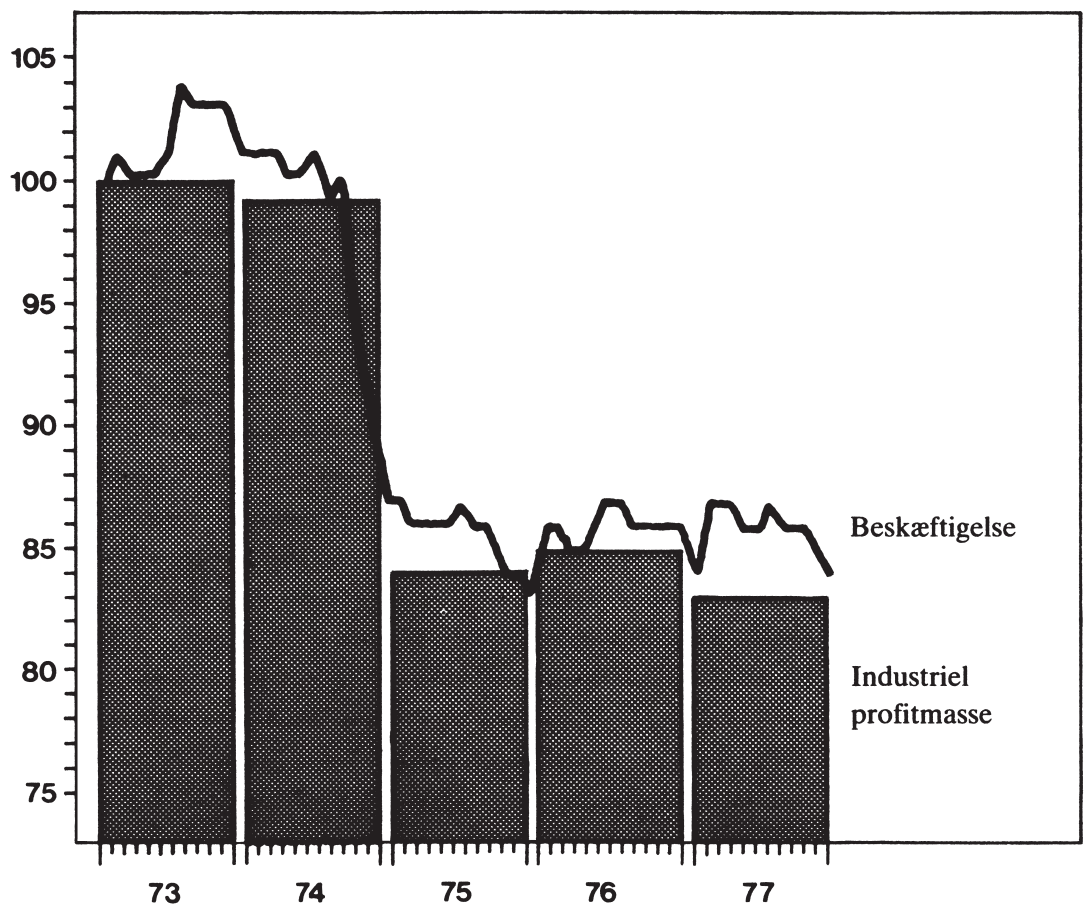

Kilde: Beskæftigelse, indeks januar 1973 = 100, fra Statistiske Efterretninger, div. numre. Profitmasse, indeks $1973=100$, beregninger på basis af Industristatistikken, div. årg.

gennem de relative merværdiproduktionsmetoder, det forudsætter udvikling i arbejdets produktivkraft.

Både produktivkraftudvikling og øget produktiv beskæftigelse forudsætter akkumulation i stor skala. Da krisen er en overakkumulationskrise, vil enhver yderligere akkumulation skærpe krisen. Det betyder, at kapitalens muligheder for at forøge totalprofitmassen gennem forvandlinger af den umiddelbare produktionsproces er blokeret. Det betyder også, at krisen ikke er af midlertidig karakter; den kan ikke overvindes på det hidtidige akkumulationsgrundlag. Profitmassen er mindsket i et sådant omfang, at 
de såkaldte gyldne 60'ere eller rettere de kapitalforgyldende 60'ere epoke definitivt er slut. ${ }^{20}$

Udbytningsgraden er imidlertid ikke kun afhængig af udviklingen i arbejdets produktivkraft. En stigende udbytningsgrad kan også fremkaldes gennem løntryk, som betyder, at arbejdsdagens betalte del formindskes. Her spiller reservearméen en afgørende rolle. I kraft af krisen producerer kapitalen en forøgelse af den industrielle reservearmé. Afhængig af hvor stor og flydende denne reservearmé er, vil den trykke lønnen, og dermed frembringe en stigende udbytningsgrad. Det er et spørgsmål om kapitalens aktion, arbejderklassens modaktion, men også et spørgsmål om karakteren af den statslige krisepolitik.

\subsection{Rammerne for den statslige krisepolitik}

Udfra statsapparatets $\varnothing$ konomiske grundlag og udfra krisens karakter skal vi opstille de logiske muligheder, som statsapparatet kan følge, forsåvidt den statslige krisepolitik sigter på at løse krisen eller ophæve dens umiddelbare virkninger på kapitalens grundlag.

Udgangspunktet for den statslige krisepolitik må i såfald være profitmassens størrelse og hvordan staten kan frembringe en forøgelse af den. Når vi som her tager udgangspunkt i skattens distribution til statsapparatet og anvendelsen af det statslige profitfond, så er der logisk set to veje, som statsapparatet kan følge, svarende til de to tidligere nævnte fronter:

1) Den indbyrdes front mellem stat og kapital. Krisepolitikken vil her bestå i en ændring af profitmassens delingsforhold mellem stat og kapital, d.v.s en formindskelse af den del af profitmassen, som statsapparatet beslaglægger. Det kan principielt ske på følgende måde:

a) Ændringer i statsbudgetterne, således at en større del af det statslige profitfond redistribueres direkte til kapitalen som privat akkumulationsfond (som erhvervstilskud). Forudsætter enten underskudsfinansiering gennem optagelse af statslån, eller en reduktion af det omfang, hvormed statsapparatet bidrager til den samfundsmæssige reproduktion, d.v.s. besparelser på alle øvrige områder.

b) Reduktion af den del af profitmassen, som distribueres til staten gennem sankning af beskatningen. Forudsætter underskudsfinansiering ved opta-

20. Kapitalens akkumulationsbetingelser under den nuværende krise og ændring i akkumulationsform findes behandlet i Tyge Kjar: Noter om eventuelle opsvingstendenser eller fortsatte stagnationstendenser under den nuværende krise; i: Projektkommentarer, bd. 2, RUC-TEK/ SAM 1979, s. 187-206. 
gelse af statslån eller besparelser på budgetterne (de områder, som besparelserne sker på, er uden betydning i denne sammenhæng). Sænkning af beskatningen har to hovedformer: (1) Sænkning af erhvervsbeskatningen, d.v.s. en reduktion i de skatter, som distribueres direkte fra kapital til stat (beskatning af selskabsprofitter, kapitalrevenuer, m.v.); mulighederne er begrænsede, da hovedparten af skatten distribueres via lønformen, jvf. tabel 1. (2) Sænkning af den del af skatten, som distribueres via lønformen; dette forudsætter en modsvarende reduktion i de nominelle lønninger og dermed i den variable kapital, forudsætter altså eksistensen af et løntryk. Hvis ikke, forbliver skattelettelsen hos lønarbejderen, og resulterer dermed i den tidligere nævnte omvendte sekundære udbytning.

2) Den faelles front mod arbejderklassen. Krisepolitikken drejer sig her om at forøge totalprofitmassen; da dens størrelse er et resultat af antallet af produktive arbejdere og udbytningsgradens samfundsmæssige størrelse, må krisepolitikken her virke i forhold til disse to.

Statsapparatets muligheder for direkte at $\emptyset \mathrm{ge}$ antallet af produktive arbejdere og udbytningsgraden er meget begrænset, ${ }^{21}$ men statsapparatet kan indirekte påvirke udbytningsgraden ved at sænke reproduktionsniveauet for den del af arbejderklassen, hvis reproduktion tilvejebringes gennem statsapparatet. Her findes to principielt forskellige muligheder:

a) Reduktion af de statslige lønarbejderes nominelle lønninger, d.v.s. underbetaling, med det formål at mindske konkurrencen mellem stat og kapital om den forhåndenværende arbejdskraft, og at fremtvinge et fald i lønningerne for de produktivt beskæftigede lønarbejdere. Forudsætningen for denne krisepolitik er, at statsapparatet som arbejdsgiver kan påvirke det samlede arbejdsmarked. Grænserne for den statslige underbetaling er det punkt, hvor statsapparatet ikke længere kan skaffe den nødvendige arbejdskraft. Den statslige underbetaling indebærer i sig selv en besparelse på budgetterne - ikke som middel, men som resultat - nemlig på den del af statsmidlerne, som anvendes til $\mathrm{k} ø \mathrm{~b}$ af arbejdskraft.

21. Det er naturligvis ikke ment som en almengyldig påstand; det gælder kun for kapitalisme af nærværende slags, hvorom der kan siges følgende: staten kan ikke direkte påvirke udbytningsgraden gennem akkumulation. Det er kapitalen, som akkumulerer, ikke staten. Staten kan heller ikke påvirke udbytningsgraden direkte gennem løntryk. Det er kapitalen, som trykker lønnen. Det er kapitalen, som er køber til den produktive arbejdskraft, ikke staten. Staten kan ganske vist forcere og almengøre et i forvejen etableret løntryk. Det belyser vi nærmere i afsnit 3. 4, jvf. også her note 24. Hertil kommer, at vi mener, at karakter og funktion af den indkomstpolitik, som føres efter krisegennemslaget, i almindelighed er blevet misforstået; det redegør vi for i det senere. 
b) Sænkning af reproduktionsomkostningerne for den del af arbejderklassen, som ikke reproduceres gennem lønarbejdet, men reproduceres gennem statsmidler, d.v.s. sociale nedskaringer. Formålet er at fremkalde en stigende konkurrence mellem den beskæftigede og den ubeskæftigede del af arbejderklassen, d.v.s. gøre reservearméens løntrykkende funktion mere virkningsfuld. Besparelserne forudsættes ikke at angå hele det sociale område, men kun den del af statsmidlerne, som anvendes til reproduktion af den arbejdsduelige, men ubeskæftigede del af befolkningen.

Stigende beskatning via lфnformen hører egentlig også med under den fælles front mod arbejderklassen, selvom den ikke har helt samme karakter, som de to foregående:

c) Stigende beskatning via lønformen fører som tidligere nævnt til sekundær udbytning, som betyder, at arbejdskraften sælges under dens normale værdi; udbytningsgraden vil vokse, men kun i den udstrækning og kun så længe det ikke lykkes arbejderklassen gennem et modsat rettet tryk at hæve arbejdslønnen, svarende til at arbejdskraften påny sælges til sin værdi. Hvis den sekundære udbytning gennem $\emptyset$ get beskatning lykkes, virker den på to måder: den forøger udbytningsgraden i den umiddelbare produktionsproces og den medfører besparelser på den del af statsmidlerne, som anvendes til $k \varnothing b$ af arbejdskraft; den bliver ganske vist betalt med samme pengeløn, men en større del vender tilbage til statskassen.

Øget beskatning via lønformen er imidlertid en modsigelsesfuld krisepolitik, idet den ganske vist - forsåvidt den trykker lønnen under den produktive arbejdskrafts værdi - forøger totalprofitmassen, men kun den del af profitmassen, som statsapparatet beslaglagger. For at virke som krisepolitik må den øgede beskatning derfor ledsages af foranstaltninger, hvormed forøgelse i det statslige profitfond redistribueres direkte til kapitalen som erhvervstilskud eller skattelettelser til erhvervslivet (jvf. pkt. b under »den indbyrdes front mellem stat og kapital«).

Der er en principielt afgørende forskel mellem de to hovedformer for krisepolitik, som skal illustreres med et eksempel.

Lad os forudsætte, at krisepolitikken blev gennemført så effektivt, at den genetablerede totalprofitmassen i samme størrelse som forud for krisegennemslaget. Vi tager udgangspunkt i udbytnings- og beskatningsforholdene i 1975. Profitmassen skulle i såfald forøges med ca. 17-18\%.

Skulle forøgelsen tilvejebringes ved et ændret delingsforhold mellem kapital og stat over den indbyrdes front, skulle statsapparatet sænke beskatningen 
med ca. 19\%, som vil forudsætte besparelser eller statslån på ca. 35-40 mia. kr. (i dagens priser). En så stor skattesænkning kan kun ske over lønformen, og forudsætter derfor eksistensen af et løntryk, som modsvarer skattelettelsen. Selvom denne krisepolitik handler om den indbyrdes front mellem kapital og stat, så fremtvinger dens gennemsættelse en direkte konfrontation med den stærkeste del af arbejderklassen, nemlig den beskæftigede del, som er i besiddelse af strejkevåbnet.

Skulle totalprofitmassen derimod forøges med de ca. 17-18\% gennem den fælles front mod arbejderklassen, så ser sagerne anderledes ud. Denne form for krisepolitik skal fremtvinge en stigning i udbytningsgraden i et omfang, der ville svare til en reduktion i reproduktionsomkostningerne på ca. $22 \%$, hvad der er det samme som en reduktion i de nominelle lønninger på ca. 10\% for den produktive arbejder. Lønnedgangen skal fremtvinges ved, at statsapparatet udnytter sin stilling som dominerende arbejdsgiver og sin stilling, som den der varetager den ikke-beskæftigede del af arbejderklassens reproduktion. Selvom denne krisepolitik handler om kapital og stats fælles front mod arbejderklassens produktivt beskæftigede del, så sættes den ikke igennem med et direkte angreb, men rettes derimod imod den svage del af arbejderklassen, nemlig den ubeskæftigede del, som ikke i sig selv er i besiddelse af kampmidler overhovedet.

De to hovedformer for krisepolitik handler begge om reallønsnedgang, men udfra forskellige forudsætninger og med forskellige virkninger, som vi ikke skal komme nærmere ind på her. De to politikkers afgørende forskel består i, hvilken del af arbejderklassen angrebet direkte rettes imod. Endvidere forudsætter den første reservearméens løntrykkende virkninger; den anden forsøger at etablere disse virkninger.

I virkelighedens verden optræder de to hovedformer for krisepolitik ikke nødvendigvis renlivet, men sammenblandet. Den lange række af kriseforlig fra september 1975 til påsken 1980 efterlader da også det umiddelbare indtryk, at stort set alle de logiske muligheder, vi har opstillet, har været fors $\varnothing \mathrm{gt}$.

\subsection{Summarisk oversigt over kriseforligene}

Fra krisegennemslaget frem til i dag er en væsentlig del af den statslige krisepolitik - men ikke den hele - blevet formuleret i de såkaldte forlig, idet forligene som regel har knyttet an til en umiddelbart efterfølgende finanslovsvedtagelse, og har haft til formål på forhånd at sikre det nødvendige flertal. I en analyse af krisepolitikkens udvikling kan man imidlertid ikke bygge på de aftalte forlig, fordi de som regel er holdt i almene, upræcise vendinger, hvor 
en del af formuleringerne er til udvortes brug. Den efterfølgende gennemgang skal derfor kun tjene som en kortfattet oversigt over de væsentligste punkter i forligene.

Det første kriseforlig kom i efteråret 1975 (septemberforliget); det bestod i en midlertidig momsnedsættelse og udbetaling af den daværende tvangsspareordning. Til forliget var knyttet en hensigtserklæring, som gik på en beslutning om afdæmpning af stigningstakten i pris-, indtægts- og omkostningsniveau.

Næste forlig var augustforliget 1976, som indeholdt skattelettelser på de direkte skatter og stigende afgifter med øget beskatning som resultat. Forliget indeholdt endvidere erhvervsstøtte på ca. 11/2 mia. kr., samt besparelser på henholdsvis 2 og 3 mia. kr. på de kommende års budgetter. Dette augustforlig indeholdt det første forsøg på at føre indkomstpolitik, idet der i forliget fastsattes en toårig ramme, hvorefter der årligt højest måtte udbetales to dyrtidsportioner pr. år, og den årlige lønstigning derudover højest måtte være på 2\%. Overskydende dyrtidsportioner skulle indefryses i ATP-fonden. Sidste element i forliget var afsættelse af 11/2 mia. kr. til beskæftigelsesarbejde.

Augustforliget i 1977 minder om det i 1976; det indeholder besparelser på budgettet på 2 mia. kr., øgede afgifter, suppleret med en stigning af momsen fra 15 til 18\%. Endvidere indeholdt forliget en beskæftigelsesplan på et samlet beløb på godt 81/2 mia. kr., fordelt over fire år. Planen, hvis væsentligste funktionsmåde var erhvervsstøtte, skulle forøge beskæftigelsen ved en indsats indenfor erhvervsfremme, energiområdet, bekæmpelse af ungdomsarbejdsløshed, bygge- og anlægsarbejder, m.v.

Det tredie augustforlig i 1978 var i det væsentlige en tro kopi af de to $\varnothing \mathrm{v}-$ rige, dog uden nye beskæftigelsesforanstaltninger. Momsen forhøjes fra $18 \%$ til 20\%; der skæres ned på de offentlige investeringer (anlægsudgifterne); der gennemføres besparelser på budgettet og en forhøjelse af indkomstskatten. Endvidere formuleredes der en stramning af indkomstpolitikken med sigte på en reallønsnedgang på $1 \%$.

Kriseindgrebene i 1979 var spredt over flere begivenheder, som er delvis sammenhængende. I marts 1979 gennemførtes der et indgreb i overenskomsterne, hvor der dikteredes en nulløsning. I juni fulgte der et nyt forlig, Sct. Hans-forliget, som indeholdt afgiftsstigninger og aftale om besparelser på statsbudgettet på 21/2 mia. kr. Senere på året blev det pålagt kommunerne gennem Kommunernes Landsforening at sikre en besparelse på de kommunale udgifter. Det resulterede i udarbejdelse af et sparekatalog, som især var koncentreret om forslag til besparelser på den del af de kommunale budgetter, som vedrører reproduktionen af den ubeskæftigede del af befolkningen; sparekataloget indgik i det senere forlig i foråret 1980. 
I december 1979 gennemførtes en halveret helhedsløsning. Det oprindelige forslag til helhedsløsning indeholdt en såkaldt social kontrakt, hvorefter taktreguleringen og det bevægelige lønsystem skulle sættes ud af kraft. Modydelsen - det der skulle gøre det til en social kontrakt - skulle bestå i en overskudsdelingsordning, baseret på et centralt fond. Ingen af delene blev gennemført. Decemberindgrebene kom derefter til at bestå af følgende: en væsentlig forringelse af dyrtidsreguleringen (fjernelse af dyrtidsportioner og energipriserne ud af reguleringspristallet), forringelse af dagpengesatserne, d.v.s. af arbejdsløshedsunderstøttelsen, forringelse af garantilønsordningen, samt oprettelse af Lønmodtagernes Dyrtidsfond gennem ekspropriation af 1976-augustforligets indefrosne dyrtidsportioner. Endvidere gennemførtes forhøjelse af formue- og selskabsskatter, samt en engangsskat på landbruget som følge af gevinster ved den tidligere gennemførte devaluering på $10 \%$. Helhedsløsningen var knyttet til finanslovsvedtagelsen, hvori også var indeholdt hovedparten af Sct. Hans-forligets aftaler.

I foråret 1980 gennemførtes det uden tvivl mest vidtgående forlig (Påskeforliget). Forligets hovedindhold var: erhvervs- og beskæftigelsesfremme på ialt 51/2 mia. kr., hvor en væsentlig del bestod i lettelser i erhvervsbeskatningen; en række arbejdsmarkedspolitiske foranstaltninger for at skabe en »forbedring af arbejdsmarkedets funktionsevne «; afgifts- og skatteforhøjelser på ialt 5 mia. kr., d.v.s. momsforhøjelse, energiafgifter samt forhøjelse af indkomstbeskatningen; og endelig besparelser på de offentlige budgetter på ialt 8 mia. kr., fordelt med ca. 41/2 mia. kr. på statsbudgettet og 311/2 mia. kr. på de kommunale budgetter.

Stort set alle kriseforligene indeholder besparelser. Det er imidlertid vigtigt at gøre sig klart, at der er tale om besparelser på budgetterne på et kommende finansår, og ikke besparelser i forhold til et foregående finansår. Besparelserne på budgetterne har ikke været så omfattende, at det (endnu) har medført et fald i de samlede statsudgifter, således som det fremgår af tabel 7.

Tabel 7. Statsudgifternes udvikling angivet ved den årlige procentvise vækst i forhold til året forud; regnet i faste priser.

\section{0}

Statsudgifternes

vækst i procent:

$$
1,1 \quad 11,2 \quad 3,6 \quad 3,4 \quad 4,5 \quad 5,5 \quad 3,1
$$

Kilde: Finansministeriets beregninger, jvf. Folketingets Forhandlinger, nr. 7, 1979-80, sp. 2822 , samt Budgetredegørelse 1980, Kbh. 1980, s. 252. 
Besparelser på budgettet sigter på at reducere vaksten i statsudgifterne; i det seneste forlig (Påskeforliget, 1980) regnes der med »gradvis at bringe realstigningen i de samlede offentlige udgifter til oph $\varnothing \mathbf{r}$ «. Statsudgifternes stigning i 1960'erne og 1970'erne er meget snævert forbundet med den betydning, det samlede statsapparat har for den samfundsmæssige reproduktion; statsudgifterne stiger, fordi kapitalen ikke er i stand til at varetage den samfundsmæssige reproduktion i en form, som betyder reproduktion af de kapitalistiske produktionsbetingelser. Det har krisen intet ændret ved; på en række punkter har den snarere nødvendiggjort stigende statsudgifter.

Besparelser er imidlertid mange ting. Som vi viste i oversigten over krisepolitikkens logiske muligheder, kan besparelser på statsbudgettet være knyttet til profitmassens delingsforhold mellem stat og kapital; for at virke skulle besparelserne her være så store, at det medførte et realfald i statsudgifterne, med mindre en del af statsudgifterne blev tilvejebragt gennem statslån. Placeringen af besparelserne var ligegyldige, blot de ikke førte til reduktion i erhvervstilskudene. Var besparelserne derimod knyttet til stat og kapitals fælles front mod arbejderklassen, så behøvede besparelserne ikke at være slet så store, men de skulle være rettet specifikt mod de statslige lønarbejdere og den del af arbejderklassen, som reproduceres gennem statsapparatet.

\subsection{Udviklingstendenser i krisepolitikken}

For at belyse udviklingstendenserne i krisepolitikken skal vi vende tilbage til spørgsmålet om, hvordan den statslige krisepolitik indvirker på totalprofitmassens størrelse. Vi skal m.a.o. undersøge den konkrethistoriske udfoldelse af de logiske muligheder for krisepolitikken, som vi tidligere opstillede.

Den lange række af forlig og kriseindgreb har mange ensartede træk. Til trods herfor er der klare udviklingstræk i krisepolitikken. Det strukturerende for krisepolitikken ved krisens begyndelse har været den indbyrdes front mellem stat og kapital, d.v.s. en ændring af totalprofitmassens fordeling mellem stat og kapital; medens det strukturerende for de seneste års krisepolitik har været den fælles front mod arbejderklassen, hvor krisepolitikken med andre ord har sigtet på en absolut forøgelse af totalprofitmassen gennem en stigende udbytningsgrad. Om den ene eller anden form for krisepolitik er strukturerende for den aktuelle krisepolitik må ikke opfattes som et udslag af den krisepolitik, som eksplicit formuleres f.eks. i forligene; men er et sammenfattende resultat af de materielle betingelser for kapital, stat og arbejderklasses ageren under de givne historiske omstændigheder. 
Lad os rekapitulere problemstillingen. Krisegennemslaget førte til et fald i totalprofitmassen gennem faldende beskæftigelse af produktive arbejdere. Kapitalens muligheder for at bringe profitmassen til at stige gennem akkumulation er på grund af krisens karakter ikke til stede. Eneste mulighed tilbage for kapitalen er at frembringe en tvangsmæssig sænkning af den variable kapital. Bestræbelserne er mangfoldige fra arbejdsgivernes side. ${ }^{22}$

Den variable kapital består dels af arbejdskraftens reproduktionsomkostninger (prisudtrykket for arbejdskraftens værdi) og dels af den del af profitmassen, som distribueres via lønformen til statsapparatet som skat. Hvis kapitalen ikke umiddelbart kan frembringe et fald i den variable kapital, som ville være ensbetydende med et fald i reproduktionsomkostningerne, så består der en mulighed $i$, at staten beslaglægger en mindre del af den del af totalprofitmassen, som distribueres via lønformen til statsapparatet, og dermed ændrer profitmassens delingsforhold mellem stat og kapital. Det forudsætter skattelettelser til den produktive arbejder, som selvfølgelig kun kan gennemføres som skattelettelse til alle lønarbejdere.

Det var, hvad der faktisk skete i 1974, men især i 1975. I 1973 var skatteprocenten for lønarbejdere på 62,7\%; i 1974 reduceres den lidt til 61,6\%, men i 1975 reduceres den kraftig til 54,1\% (jvf. tabel 3).

Resultatet af skattelettelsernes konsekvenser for profitmassens delingsforhold mellem stat og kapital fremgår af figur 4. Med denne figur belyser vi udviklingen i delingsforholdet udfra, hvordan gennemsnits industriarbejderens arbejdsdag er fordelt mellem industriel profit, statsbeslaglagt profit og disponibel arbejdsløn. Det kan opfattes som et empirisk udtryk for den produktive totalarbejders udbytningsforhold, hvis man går ud fra den forudsætning, at

22. 1975 er det afgørende år, som bør sammenlignes med krisegennemslaget i 1920-21 - ikke mindst fordi der er tale om en krise af samme karakter. Dengang voksede arbejdsløsheden lige så pludseligt som nu; i 1920 fremtvang arbejdsgiverne lønnedgang for en række områder. For en række ufaglærte var lønnedgangen tæt på 50\% og for de faglærte var den på 30-35\% (jvf. forbundsberetningerne). Arbejdsgiverne havde - dog næppe som resultat af historisk bevidsthed - tydeligvis samme forventninger til krisegennemslaget i 1974/75. Første halvår af 1975 er præget af usædvanlig mange strejker, hvor hovedparten er fremprovokeret gennem lønnedsættelse og fyring af fagligt aktive; arbejdsgiverne er, som næstformanden for de københavnske typografer siger, »... begyndt at vejre morgenluft på grund af den store arbejdsløshed.« Det gælder »kampen mod omkostningerne«, som er arbejdsgivernes nye ord for arbejderklasse, jvf. særnummer af Arbejdsgiveren, 10. 5. 1976. Det går ikke så godt med at få sat løntrykket igennem. Derfor gør Arbejdsgiverforeningen sine medlemmer opmærksom på, at de kan få støtte til løntryk »... med henblik på at dæmpe lønudviklingen og afbøde konflikternes virkning for medlemmerne«; jvf. artiklen »Støtte mod lønpres«, særnummer af Arbejdsgiveren, 10. 5. 1976, s. 14, hvor det nævnes, at der ialt i 1974 blev ydet 8,2 mill. kr., men i 1975 blev ydet 36,4 mill. kr. til st $\varnothing t t e$ for kampen mod »omkostningerne $\ll$. 
industriens udbytningsforhold giver et realistisk billede af hele den kapitalistiske produktions udbytningsforhold. (Forholdenene skal være meget afvigende indenfor de $\varnothing$ vrige produktionsområder, hvis denne forudsætning ikke holder, fordi den industrielle produktion er langt den dominerende del af den kapitalistiske produktion).

Figur 4. Arbejdsdagens procentvise fordeling mellem industriel profit og variabel kapital, mellem industriel profit, statsbeslaglagt profit og disponibel arbejdsløn. Industrien; procentfordelt pr. år.

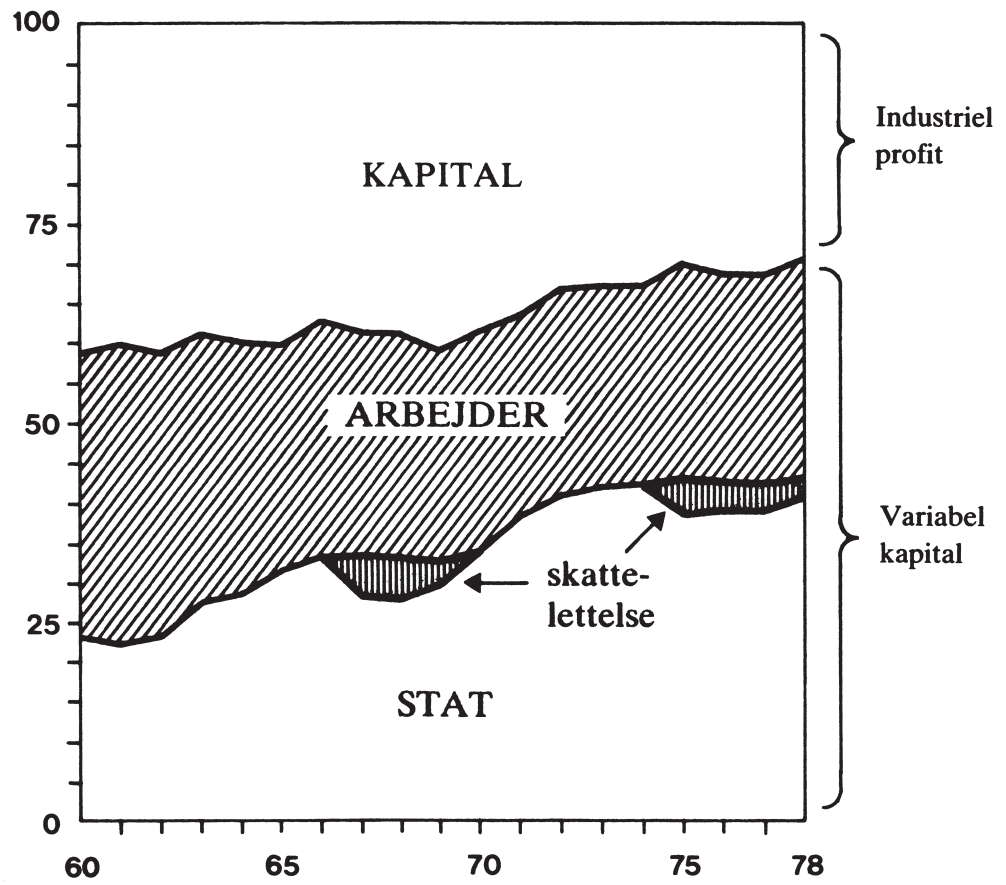

Kilde: Beregninger på basis af Industristatistikken og tabel 3; beregningsmetoder som angivet $\mathrm{i}$ note 10 og tabel 2 .

Figuren viser to karakteristiske forhold. For det første viser den den langsigtede udviklingstendens i udbytningsforholdene: arbejderens andel af arbejdsdagen er som tendens stedse reduceret, hvad der svarer til stigende udbytningsgrad, som er fremkaldt af udviklingen i den umiddelbare produktionsproces. I 1960'erne beslaglægger staten fuldt ud resultatet af den 
stigende udbytningsgrad; i 1970'erne tager den sig af mere end broderparten.

For det andet viser figuren virkningen af skattelettelser på udbytningsforholdene. Figur 4's finskraverede felter angiver resultatet af skattelettelserne, som - fordi skatten distribueres via lønformen - umiddelbart fører til en forøgelse af den disponible arbejdsløn, d.v.s. en forøgelse af reproduktionsniveauet.

I forbindelse med krisen i 1966/67 gennemførtes der - på samme måde som i 1974/75 - en skattelettelse (jvf. tabel 3); den var ledsaget af andre indgreb, men fors $\varnothing \mathrm{g}$ på indefrysning af dyrtidsportioner lykkedes som bekendt ikke. I 1966/67 udeblev resultatet heller ikke; skattelettelserne blev i løbet af nogle år omsat i et relativt fald i den variable kapital, og den industrielle profit voksede. Det sammen med 1960'ernes generelle akkumulationsbetingelser og denne krises specifikke art førte da også til en hurtig overvindelse af krisen i $1966 / 67$.

På grundlag af det løntryk, som gjorde sig gældende i perioden, lykkedes den krisepolitik, som handler om den indbyrdes front mellem stat og kapital. Efter krisens afslutning, hvor akkumulation og produktivkraftudvikling i den umiddelbare produktionsproces påny fremkaldte en stigende udbytningsgrad, blev den hidtidige udvikling med stedse stigende skatteprocenter genoptaget, d.v.s. statsapparatet beslaglagde påny en stigende del af profitmassen. Den forøgelse af statsgælden, som var en forudsætning for skattelettelse, afvikledes ikke helt, men dog for en stor dels vedkommende i begyndelsen af 1970'erne - inden krisegennemslaget i 1974/75 (jvf. tabel 4).

Det gik ikke på samme måde i begyndelsen af den nuværende krise. Skattelettelsen omsættes ikke i en udpræget faldende variabel kapital; slet ikke i et fald, som modsvarer skattelettelsen (jvf. figur 4). Og derfor heller ikke i en faldende realløn; reallønsudviklingen stagnerer, men den falder ikke generelt for de produktive arbejdere. ${ }^{23}$

23. Reallønnen kan opgøres på forskellig måde: som årsløn eller som timeløn - uden væsentlige forskelle kan konstateres. I den senere tabel 8 er de opgjort i timel $\varnothing$ n for industriens arbejdere på basis af Industristatistikken. Statistiske Efterretningers oplysninger, som er baseret på løbende indberetninger fra arbejdsgiverne, viser samme udviklingstendens, hvis reallønnen opgøres som årsgennemsnit. Kvartalsvise opgørelser viser imidlertid nogle variationer. Hvis januar-kvartal 1974 sættes lig indeks 100, vokser reallønnen for industri og håndværk til indeks 114 i sidste kvartal af 1975; i 1976 svinger den mellem 112-113; i juli kvartal 1977 når den op på indeks 116. Der er store lønforskelle i industrien efter alder, køn, kvalifikation, region og branche (jvf. Johs. Due: Lønudviklingen for arbejdere efter 1950, Arbejdsnotat 2, Lavindkomstkommissionen, Kbh. 1979). Den største lønforskel er mellem brancher. Sættes industriens arbejderes realtimeløn til indeks 100 for 1974, så stiger den til indeks 112 i 1977. Drikkevareindustrien (bryggerierne bl.a.), som er den branche, der har højest timeløn, har i 
Det er her vigtigt at klargøre de materielle forudsætninger i forhold til kapital og lønarbejde for den krisepolitik, som handler om den fælles front mellem stat og kapital.

For det første er det en krisepolitik, som hurtigt kan iværksættes og den kan principielt iværksættes med ubegrænsede midler i et kortere åremål; det afhænger kun af størrelsen af de statslån, som skal optages for at finansiere skattelettelsen eller rettere finansiere den mindskede distribution af profit til statsapparatet. Den forudsætter imidlertid hurtig virkning på den variable kapital, idet omfordelingen mellem stat og kapital skal ske over et kort åremål; ellers vil statslånene vokse til uhørte størrelser og renterne af statsgælden vil beslaglægge så store dele af statsudgifterne, at statens deltagelse i den samfundsmæssige reproduktion vil blive væsentligt beskåret. Som krisepolitik er den derfor knyttet til kapitalens cykliske svingninger, som den nuværende krise ikke kan betegnes som. Politikken kan - om man vil - karakteriseres som en konjunkturregulerende politik.

For det andet forudsætter denne krisepolitik, at reduktionen i den variable kapital påny kan bringe kapitalakkumulationen i stand; det er et spørgsmål om reduktionens størrelse, men isar et spørgsmål om i forvejen eksisterende akkumulationsbetingelser, nemlig et »opsving lige rundt om hjørnet«. Derfor var den som krisepolitik virkningsfuld for kapitalakkumulationen under den intensive akkumulationsfase.

For det tredie baserer denne krisepolitik sig på eksistensen af et løntryk. Den forudsætter, at krise har skabt arbejdsløshed, og at arbejdsløshed har skabt løntryk. Er løntrykket ikke til stede, bliver denne krisepolitiks logiske konsekvens, at staten for at gennemsætte den må fremtvinge et løntryk. ${ }^{24}$

1974 en realtimeløn på indeks 134; den vokser i 1975 til indeks 149, falder i 1976 til 138, men vokser igen i 1977 til 149. Fodtøj- og beklædningsindustrien, som er branchen med den laveste timeløn, har en realtimeløn på indeks 78 i 1974, den vokser til 84 i 1975, 88 i 1976, og 91 i 1977. (Branchelønningerne er baseret på Industristatistikken).

24. Som nævnt kan staten ikke direkte skabe et løntryk. Det er reservearméens størrelse, og hvor flydende den er, der bestemmer eksistensen af et løntryk. Det formidles over en række delarbejdsmarkeder (opdelt efter region, branche, køn, kvalifikationer og alder), hvor det afgørende er omfanget af konkurrencen kapitalerne indbyrdes om arbejdskraften og omfanget af konkurrencen mellem arbejderklassens beskæftigede og ubeskæftigede del. Det må være selvklart, at staten ikke ved løndiktat påvirker denne konkurrence - den er afgjort af andre forhold. Men hvis løntrykstendenser er til stede kan staten accelere og almengøre dette løntryk. Det hænger sammen med følgende forhold. Den produktive arbejders $1 \emptyset n$ reguleres gennem tre forhold: overenskomsten, som fornyes hvert andet år; pristalsreguleringen, som giver delvis kompensation for prisstigninger; og lønglidning, som er. 1ønstigninger der opnås mellem overenskomsterne - for minimallønsområdet gennem løbende (som regel kvartalsvise) overenskomstmæssigt fastsatte forhandlinger og normallønsområdet ved overenskomststridige strejker. Dette gælder for timelønnede; for akkordlønnede 
Selvom krisepolitikken handler om profitmassens sens deling mellem stat og kapital, så fremtvinger den således en konfrontation med arbejderklassens beskæftigede del fra statens side.

Denne logiske konsekvens blev da også fulgt, idet man kort efter krisegennemslaget lancerede indkomstpolitikken som led i krisepolitikken. Det er da også hovedindholdet i de fleste af forligene og kriseindgrebene frem til 1979. Det handler især om overenskomsterne og dyrtidsportionerne. I december 1979 var der endog lagt op til et direkte indgreb i det bevægelige lønsystem for at stoppe lønglidningen. Det blev som tidligere nævnt ikke til noget.

En kort oversigt over forlig og indgreb viser tydeligt, at det er overenskomster og dyrtidsregulering, som er i centrum: i foråret 1975 greb regeringen ind i overenskomstforhandlingerne og forlængede overenskomsterne uændrede, dog med et mindre tillæg til de lavestlønnede; samtidig ændredes dyrtidsreguleringen fra en procentregulering til et fast ørebeløb pr. dyrtidsportion, d.v.s. inflationen blev bygget ind i selve reguleringen. I følge septemberforliget 1975 skulle staten kompensere for de lønstigninger, der oversteg mere end én dyrtidsportion ved januar og juli-reguleringerne i 1976.

Augustforliget 1976 fastsatte rammerne for den overenskomst, der skulle løbe fra marts 1977 til marts 1979. På overenskomsten måtte der ikke gives mere end 2\%'s stigning pr. år, og der måtte kun komme to dyrtidsportioner til udbetaling pr. år. En lang række overenskomststridige strejker i efteråret 1976, hvor de strejkende forsøgte at opnå lønstigninger inden augustforligets ikrafttræden marts 1977, førte til et forslag om kriminalisering af overenskomststridige strejker, som dog ikke blev gennemført på grund af LO's modstand. I stedet gennemførtes der et pris- og lønstop i december 1976, som løb frem til de nye overenskomster i marts 1977, og som medførte at en dyrtidsportion ved januar 1977-reguleringen ikke blev udløst og at lønstigninger opnået ved overenskomststridige strejker inden marts 1977 skulle modregnes i de opnåede stigninger ved overenskomsten i 1977.

\footnotetext{
kan der - uanset lønområde - sikres lønstigninger gennem ændringer i akkordsatser og akkordsystemer; det forudsætter ikke nødvendigvis overenskomststridige strejker. Bevarelse af reallønnen forudsætter stigende nominelle lønninger på grund af inflationen, som efter krisegennemslaget har svinget mellem 7-15\%. Man kan derfor sige det på følgende måde: de nødvendige lønstigninger kan opnås på to måder, dels i forhold til de centralt fastsatte forhold (overenskomst og pristalsregulering), og dels i forhold til de lokale forhold. Staten kan gribe ind i de centrale forhold. Det medfører, at de nødvendige lønstigninger udelukkende skal sikres gennem de lokale aftaler. Det stiller krav til den faglige organisering, kræver for en række områder udvikling af nye faglige traditioner, og fremfor alt forudsætter det, at de materielle betingelser - den omtalte konkurrence - muligg $ø$ r det. Hvis dette ikke er tilfældet, hvis der findes tendenser til løntryk, så kan indkomstpolitikken virke forcerende og almengørende af dette løntryk.
} 
Overenskomstforhandlingerne i foråret 1977 endte med, at forligsmandens mæglingsforslag blev ophøjet til lov. Den lovfastsatte overenskomst indebar en timelønsforhøjelse ens for alle, fordelt halvårligt på 4 rater á $70 \varnothing$ rer, svarende til ca. 1\%'s forhøjelse af overenskomsten (det var augustforligets ene procent, forudsætningen var derfor, at lønglidningen også skulle holdes på 1\% pr. år). Endvidere gennemførtes en garanteret mindsteløn på 29,- kr. som dog kun var pristalsreguleret.

I augustforliget 1978 formuleredes der - med sigte på den kommende overenskomst fra marts 1979 til marts 1981 - en stramning af indkomstpolitikken med sigte på en reallønsnedgang på 1\%. I foråret 1979 greb staten ind i overenskomstforhandlingerne og dikterede en uændret forlængelse af overenskomsterne, bortset fra garantilønnen, som blev forhøjet ekstraordinært med $1,20 \mathrm{kr}$; den var sakket meget agter ud som følge af lønglidningen.

I december 1979 greb man ind i dyrtidsreguleringen, idet oliepriserne og deres stigning blev taget ud af det lønregulerende pristal med tilbagevirkende kraft fra 1. januar 1979, samtidig blev beregningsgrundlaget ændret (nulstilling af indekset); alt i alt betød det fjernelse af 31/2-4 dyrtidsportioner.

1975-overenskomsten var en 0,5\%'s løsning (kun tillæg til de lavestlønnede); 1977-overenskomsten var en 4\%'s løsning; medens 1979-overenskomsten var en 0-løsning. Ca. 151/2-16 dyrtidsportioner blev indefrossent eller fjernet; som følge af fast $\varnothing$ rebel $\varnothing$ b pr. dyrtidsportion (60 øre i 1975 og siden da uændret), er købekraften af en dyrtidsportion fra 1975 til i dag forringet med 35-40\%.

Til trods for indgrebene i overenskomsterne og i dyrtidsreguleringen lykkedes det alligevel arbejderne gennem lønglidning at fastholde reallønnen og i perioder endda at bringe den til at stige moderat. Begivenhederne viste, at staten hverken har kunnet forcere eller almengøre de spredte tendenser til løntryk fra kapitalens side, som helt klart forekommer i perioden. De materielle betingelser for et alment løntryk findes ikke; eller - hvad der er det samme - de materielle betingelser for, at arbejderklassen kan udøve et modsat rettet tryk er til stede.

Allerede i 1976 havde Det $\varnothing$ konomiske Råds Formandsskab fået nok. Indkomstpolitikken kunne ikke bruges, fordi »... En betydelig del af lønstigningerne finder sted ved lokale forhandlinger, til dels uden for hovedorganisationernes kontrol. Også med en svag arbejdskraftefterspørgsel vil det være forbundet med vanskeligheder at holde lønudviklingen inden for snævre rammer, selv i tilfælde af at sådanne rammer accepteres både af organisationerne og på arbejdspladserne. $\ll^{25}$

25. Jvf. Dansk фkonomi, april 1976; udarbejdet af Det фkonomiske råds formandsskab; Kbh. 1976, s. 83. 
Indgrebene i overenskomsterne og i dyrtidsreguleringen har betydet, at de nominelle lønstigninger skal hentes hjem over lønglidningen. Det har givet et helt nyt grundlag for den aktive fagforeningspolitik. ${ }^{26}$

Sammenfattende: ændring af totalprofitmassens delingsforhold mellem kapital og stat forudsætter en sænkning af lønarbejderbeskatningen, fordi hovedparten af skatten distribueres via lønformen til statsapparatet. Det forudsætter løntryk. Da løntrykket ikke generelt var tilstede måtte staten gennem en indkomstpolitik forsøge at fremtvinge et løntryk. Det lykkedes heller ikke. En krisepolitik struktureret omkring den indbyrdes front mellem stat og kapital måtte derfor opgives. Den indkomstpolitik, som er knyttet til den profitmasseomfordelende krisepolitik, er sammen med den krisepolitik, den var knyttet til, opgivet for stedse. Indkomstpolitik i denne form er en død sild.

Udviklingens resultater kan sammenfattes i nedenstående tabel.

Tabel 8. Udvikling i udbytningsgrad (i procent), realtimeløn (indeks), disponibel realtimeløn (indeks), skatteprocent og statslån (løbende priser i mia. kr.) i perioden 1971-78.

\begin{tabular}{lrrrrrrrrr}
\hline & 1971 & 1972 & 1973 & 1974 & 1975 & 1976 & 1977 & 1978 \\
\hline $\begin{array}{l}\text { Udbytningsgrad: } \\
\begin{array}{l}\text { Udbytningsgrad uden } \\
\text { skattelettelse: }\end{array}\end{array}$ & 287 & 292 & 304 & 279 & 211 & 243 & 248 & 247 \\
$\begin{array}{l}\text { Realtimeløn for } \\
\text { industriens arbejdere: }\end{array}$ & - & - & - & - & 272 & 284 & 283 & 274 \\
$\begin{array}{l}\text { Disponibel realtimeløn for } \\
\text { industriens arbejdere: }\end{array}$ & 100 & 106 & 115 & 121 & 135 & 135 & 136 & 137 \\
$\begin{array}{l}\text { Skatteprocenten: } \\
\text { Statsgælden - mia. kr.: }\end{array}$ & 59,4 & 61,6 & 62,7 & 61,6 & 54,1 & 57,0 & 57,7 & 58,6 \\
\hline
\end{tabular}

Kilde: Egne beregninger som i figur 4; realtimeløn og disponibel realtimeløn er deflateret med forbrugerprisindekset. Det må understreges, at opgørelsen over statslån er statslån og ikke statsgæld, da formålet er at give et billede af lånoptagningen. Statslånene er opgjort pr. 1. marts. Ved udgangen af 1978 var statslånene vokset til 74,3 mia. kr., ved udgangen af 1979 var den 98,1 mia. kr. Udenlandske lån udgør en væsentlig del af lånene; i marts 1978, hvor udenlandslånene udgjorde den største andel, var de på knap 48\% af statslånene. Jvf. Danske Statslån 1979; Finansministeriet, Kbh. 1980, s. 21.

26. Det er derfor logisk - men selvmodsigende i forhold til den hidtil førte politik - at Finansministeriet i den seneste budgetredegørelse taler om nødvendigheden af, at sikre realindkomsten for lønmodtagere i den private sektor; fordi »... der er en risiko for, at de beskæftigede lønmodtagere i den private sektor ikke vil acceptere at få deres disponible realindkomst reduceret, og at de derfor vil reagere ved at søge kompensation gennem større nominelle lønstigninger«, Budgetredegørelse 1980, Sammenfatning, Kbh. 1980, s. 11 (vores fremhævelse). 
Tabellen viser, at udbytningsgraden, som i 1970'ernes begyndelse var langsomt voksende i forhold til 1960'erne, også er faldende i krisen (304\% i 1973; 272\% i 1975), hvis vi ser bort fra effekterne af skattelettelsen og det udeblevne, generelle løntryk. Det hænger sammen med braklægningen i den umiddelbare produktionsproces og dens effekter på den mængde produkter, som materialiseres pr. arbejder. Endvidere spiller konkurrenceforholdene på verdensmarkedet ind på denne udvikling.

Hvis den krisepolitik, som blev iværksat ved krisegennemslaget, skulle være vellykket set fra kapitalens standpunkt, så skulle den faktiske udbytningsgrad have befundet sig mindst på et niveau svarende til 280\% i 1976-77. For 1977's vedkommende ville det have betydet en realløn, som var ca. $4 \%$ mindre end den faktisk blev, og en disponibel realløn, som var $9 \%$ mindre end den faktiske. Det ville naturligvis ikke have løst krisen; de nødvendige akkumulationsbetingelser er - som tidligere ikke til stede; men det ville have givet kapitalen en forøgelse af profitmassen, som ville svare nogenlunde til den størrelse, den havde umiddelbart efter krisegennemslaget.

Uanset om denne krisepolitik lykkedes eller ej, så ville den - og har den efterladt en stor statsgæld, som kun kan dækkes ind gennem en stigende beskatning, der - hvis den ikke skal ændre på profitmassens delingsforhold mellem stat og kapital - skal gennemføres som en sekundær udbytning gennem beskatning. Den del af krisepolitikken er indledt og mere er i vente.

Tabel 8 viser endvidere, at statsgælden vokser. Stigningen de første år er som tidligere nævnt forbundet med finansieringen af skattelettelsen i 1975 og de efterfølgende år. Også skatteprocenten udviser stigende tendens siden 1975. Med momsforhøjelsen fra augustforliget i 1978, med momsforhøjelsen ved Skt. Hans-forliget i 1979, og med de stigende afgifter, indkomstskat og moms fra Påskeforliget 1980 er der ingen tvivl, at skatteprocenten nu er noget over 1973-74 niveauet. Det er imidlertid ikke endnu muligt at belyse det empirisk. Den stigende skatteprocent er udtryk for to forhold; dels er den et udtryk for, at statsapparatet må gensikre sig mindst samme andel af totalprofitmassen som før krisegennemslaget; og dels er den et led i nye tendenser i krisepolitikken.

Noget lignende gælder den voksende statsgæld; i 1979 voksede statsgælden med 24 mia. kr.; det skyldes nu ikke længere finansiering af skattelettelsen - den er væk - men derimod, dels at statsapparatet ikke har sikret sig en stigende andel af profitmassen, modsvarende kriseårenes stigende statsudgifter (disse stigninger må lånefinansieres), og dels er den et led i nye tendenser i krisepolitikken.

Med kriseforlig og kriseindgreb i 1978 og 1979, men især 1980 formuleres der nye tendenser i krisepolitikken, hvis strukturerende element er kapital og stats fælles front mod arbejderklassen. 
Lad os kort rekapitulere hvad den består i. Den drejer sig om at få totalprofitmassen til at vokse, og ikke som ved den hidtidige krisepolitik om at ændre på profitmassens delingsforhold mellem stat og kapital. Profitmassen kan statsapparatet bringe til at stige, hvis den kan fremtvinge en stigende udbytningsgrad.

Det kan staten for det første gøre ved at $\varnothing$ ge beskatningen via lønformen og samtidig redistribuere den $\varnothing$ gede beskatning til kapitalen; d.v.s. gennemsætte en sekundær udbygning gennem beskatning. Forudsætningen for denne politik er, at den produktive arbejders realløn ikke vokser væsentligt, og at den disponible realløn som følge af stigende beskatning falder. Den forudsætter derfor ikke - som den hidtidige krisepolitik - at reallønnen for den produktive arbejder direkte skal falde. Det er en hurtigt virkende, men uden tvivl en midlertidig krisepolitik, fordi der er historiske og objektive grænser for statsapparatets sekundære udbytning gennem lønbeskatning og for størrelsen af den profitmasse, som via skattelettelsen kan redistribueres til kapitalen.

For det andet kan staten bringe udbytningsgraden til at stige ved at skabe betingelser for løntrykket; d.v.s. skabe materielle betingelser for, at arbejderklassen ikke effektivt nok kan udøve et modsat rettet tryk mod kapitalens løntrykstendenser.

Etableringen af de materielle betingelser for $\emptyset$ get løntryk er generelt et spørgsmål om at sænke reproduktionsniveauet for arbejderklassens ubeskæftigede del, som suverænt fastsættes af statsapparatet; specifikt er det et spørgsmål om at sænke arbejdsløshedsundersøttelsen og fjerne alle de elementer i arbejdsmarkeds- og socialpolitikken, som under den intensive akkumulationsperiode har haft til formål at gøre reservearméen større og mere flydende ved at holde reproduktionsniveauet for den ubeskæftigede del så højt som muligt. Som tidligere nævnt betyder en sådan krisepolitik derfor, at angrebene primært rettes mod arbejderklassens svageste led.

Vi er afskåret fra empirisk nøjere at analysere de nye tendenser i krisepolitikken - de er dårligt nok sat igennem - men de seneste forlig og indgreb kan sammenfattes i tre punkter, som understreger de nye tendenser i krisepolitikken: ${ }^{27}$

27. Vi skal ikke gennemgå forliget i detaljer men henvise til den grundige gennemgang $\mathrm{i}$ Firepartiforliget Maj 1980 - Facts, argumenter, vurderinger; udarbejdet af VS's nedskæringsgruppe, Kbh. 1980, samt til Aftale mellem Socialdemokratiet, Radikale Venstre, Centrumdemokraterne og Kristeligt Folkeparti; 5. maj 1980, og til Udbygning af flerårigt фkonomisk-politisk handlingsprogram - regeringens erklaring af 7. april 1980, Budgetdepartementet, Småtryk nr. 13A, Kbh. 1980. 
1) Redistribution af profitmasse til kapitalen gennem $\varnothing$ get beskatning og $\varnothing$ get erhvervstilskud. Efter Påskeforliget 1980 skal skatte- og afgiftsstigninger ialt i 1981 indbringe 5 mia. kr. mere. Det opnås ved stigning i indkomstskatter på 1 mia. kr.; energiafgifter på ligeledes 1 mia. kr., samt momsforhøjelse på $31 \frac{1}{2}$ mia. kr., hvoraf dog den $1 / 2$ mia. $k r$. anvendes til sociale kompensationer.

Sideløbende hermed afsættes der i Påskeforliget 51/2 mia. kr. til erhvervsog beskæftigelsesfremme; heraf hører 1,4 mia. kr. dog til under arbejdsmarkedspolitikken, jvf. nedenfor. Af de resterende 4,1 mia. kr. anvendes den væsentligste del til skattelettelser og finansieringsstøtte til erhvervslivet, hvormed den $\emptyset$ gede beskatning gennemsættes som redistribution af profitmasse til kapitalen.

2) Etablering af materielle betingelser for løntryk. Den har en arbejdsmarkedspolitisk del, som i Påskeforliget 1980 handler om udvidelse af uddannelsesindsat og arbejdsformidling; der er afsat 1,4 mia. kr. til »at sikre, at der er veluddannet arbejdskraft til rådighed, og at arbejdsformidlingen fungerer effektivt«. (Paradoksalt nok er de 1,4 mia. kr. placeret under forligets beskæftigelsesplan, og ikke under dens arbejdsmarkedspolitiske del). Hermed følges en række tidligere initiativer op, som har drejet sig dels om at opstramme ledighedsbegrebet, og dels om at gøre reservearméen mere flydende. ${ }^{28}$

Den anden del af politikken vedrørende de materielle bestingelser for løntryk handler om forringelse af arbejdsløshedsunderstøttelsen, gennemført ved helhedsløsningen i december 1979. Den vender vi tilbage til.

3) Reduktion i de statsudgifter, hvormed staten deltager i den samfundsmæssige reproduktion, men som især ikke under krisen længere har aktuel betydning for kapitalens produktionsbetingelser. Kort sagt: sociale nedskæringer, som delvis er besparelser, der er resultat af social- og arbejdsmarkedspolitiske omlægninger i forbindelse med de nye tendenser i krisepolitikken. Besparelser på ialt 8 mia. kr. sigter på, at reducere statsudgifternes realvækst i 1981 til 2\%, og realvæksten i 1982 til 1\%. ${ }^{29}$

Som tidligere nævnt er det ikke muligt at undersøge følgerne af den krisepolitik, som baseres på den fælles front mellem kapital og stat mod arbej-

28. Vedrørende de tidligere arbejdsmarkedspolitiske krisetiltag henvises til Bo Elling Nielsen: Den statslige arbejdsmarkedspolitik i krisen; i Kurasje nr. 18, s. 103-135.

29. Eller med budgetredegørelsens ord: »Det vil derfor være nødvendigt at tage fat på indkomstoverførslerne for størsteparten af de yderligere besparelser, som kræves for at etablere nulvækst. Det er samtidig den kategori af offentlige udgifter, hvor besparelser har det mest fordelagtige real-фkonomiske indhold: stor import- og lille beskaftigelseseffekt.«; Budgetredegørelse 1980. Sammenfatning, Kbh. 1980, s. 32. 
derklassen. På et punkt skal vi dog i detalje redegøre for de nye tendenser i krisepolitikken, nemlig virkningerne af en reduktion i arbejdsløshedsunderstøttelsen.

Som nævnt ændredes dagpengesatserne (dækker arbejdsløshed, sygdom og barsel) ved kriseindgrebet i december 1979. Før da reguleredes dagpengesatsernes maksimumsats to gange årligt pr. 1. januar og 1. juli i forhold til udviklingen i timelønnen for industriens arbejdere, dog med ca. ét års forsinkelse. Det betød, at dagpengene - omend forsinket - så dog fulgte reallønsstigningen i en vis afstand. Efter ændringen i december 1979 reguleres taksterne ikke længere efter den faktiske lønstigning, men skal erstattes af $» \ldots$ en forhøjelse pr. 1. september 1980 svarende til pristalsreguleringen af lønnen på arbejdsmarkedet, samt med et beløb svarende til den forventede taktregulering for offentlige ansatte i efteråret 1980. Senere skal der fremsættes forslag til nye regler gældende fra 1. marts 1981. Herved forventes den helt automatiske kobling til lфnudviklingen (incl. lфnglidning) at oph $\phi r e \ll .{ }^{30}$

Taktreguleringen, som er en regulering der skal sikre de statslige lønarbejdere andel i lønglidningen, virker kun kompenserende i begrænset omfang. Selvom den midlertidige regulering af dagpengesatserne skulle blive mere permanent, så betyder det alligevel, at dagpengenes dækningsgrad fremover vil udvise en klart faldende tendens. Udviklingen i arbejdsløshedsunderst $\varnothing t-$ telsens dækningsgrad skal belyses nærmere for ufaglærte københavnske arbejdere, jvf. oversigten i tabel 9.

Tabel 9. Udviklingen i den disponible årsløn for ufaglærte arbejdere i København, og den maksimale understøttelse, som kunne opnås, i perioden 1974-78. Indeks; arbejdsløn $1974=100$.

\begin{tabular}{lrrrrr}
\hline & 1974 & 1975 & 1976 & 1977 & 1978 \\
\hline $\begin{array}{l}\text { Disponibel realårsløn: } \\
\text { Disponibel realunder- }\end{array}$ & 100,0 & 126,2 & 123,4 & 117,8 & 119,8 \\
$\quad$ støttelse: & 85,7 & 104,7 & 101,6 & 97,7 & 98,9 \\
Dækningsgrad (i procent): & 85,7 & 83,0 & 82,3 & 82,9 & 82,6 \\
\hline
\end{tabular}

Kilde: egne beregninger på basis SFI-Publikation 88, s. 78, samt Arbejdsgiverforeningens Lønstatistik, diverse numre.

Arbejdsløshedsunderstøttelsens dækningsprocent afhænger selvsagt af den løn, som man ville kunne have opnået ved beskæftigelse, ligesom den kom-

30. Budgetredegфrelse 1980, Kbh. 1980, s. 47 (vores fremhævelse). 
munale skatteprocent spiller ind på den disponible understøttelses størrelse. Som følge af lønforskellene betyder det, at den højeste dækning som regel opnås af ufaglærte kvinder (ca. 85-88\%); den mellemste af ufaglærte, timelønnede mænd (jvf. tabel 9); og den dårligste dækning opnås af faglærte og ufaglærte på akkord; for de sidstnævnte dækker understøttelsen typisk kun omkring de 70\%. (Det må understreges, at vi i tabellen regner med disponibel realløn, disponibel realunderstøttelse; blev der regnet i de nominelle størrelser, ville dækningsprocenterne være mindre).

Hvad er virkningerne af en forringelse af understøttelsesniveauet? I en kommentar fra Arbejdsgiverforeningen til en undersøgelse foretaget af Landsarbejdsnævnet og Socialforskningsinstituttet hedder det bl.a. ${ }^{31} » \ldots$ at det tilsyneladende er væsentlig lettere at få besat stillinger, der giver en løn, som er noget højere end arbejdsløshedsdagpengene. I 58 pct. af de tilfælde, hvor dagpengene udgjorde over 80 pct. af den tilbudte $1 \varnothing n$, resulterede formidlingerne i ansættelse. I de tilfælde, hvor dagpengene udgjorde over 90 pct. af den tilbudte løn, blev kun 48 pct. af de anviste eller henviste personer ansat.« Og videre: »Det kan ikke og har aldrig været meningen, at det er dagpengesystemet, der skal bestemme lønniveauet og lønudvikling. ... vi (vil) ikke acceptere, at lønniveauet skal være bestemt af, hvor store dagpenge der ydes arbejdstagere, som ikke er i arbejde.«

Det illustrerer klart den virkning, som en arbejdsløshedsunderstøttelse vil have, der er relativt faldende og ikke længere er reguleret i forhold til timelønne i industrien. Den gør det muligt at tilbyde lavere løn, og alligevel sikre ansættelse.

Finansministeriet har allerede gjort regning på virkningerne af ændringerne i arbejdsløshedsunderstøttelsen, idet man i 1980 regner med en gennemsnitsreduktion på 1,2\% pr. arbejdsløs, og i 1981 med en reduktion på 5,8\% pr. arbejdsløs, altsammen regnet i 1979-priser. ${ }^{32}$

Arbejdsløshedsunderstøttelsen har det som med pensionsalderen - dens størrelse følger akkumulationsbevægelserne. Før krisen skulle arbejdsløshedsunderstøttelsen sammen med en række andre foranstaltninger ${ }^{33} l ø s e ~ » u d-$

31. H. Skov Christensen: Lønhøjden og produktionen; Politiken, 3. aug., 1980, 3. sek., s. 8 (vores fremhævelser).

32. Tallene fremkommer ved at sætte udgifter til arbejdsløshedsdagpengene i forhold til det antal arbejdsløse, som der regnes med i de kommende år i: Udbygning af flerårigt фkonomiskpolitisk handlingsprogram - de offentlige finanser og samfundsøkonomien, Budgetdepartementet, Småtryk nr. 13B, Kbh. 1980, s. 22, tabel 2, og s. 37, tabel 5.

33. Her må især nævnes arbejdsformidlingspolitikken, de mobilitetsfremmende ydelser; arbejdsmarkedsuddannelserne, især efteruddannelse og omskoling, revalideringspolitikken, o.s.v. Sammen med arbejdsløshedsunderstøttelsen har disse politikker især haft til formål at vedligeholde og flydendegøre reservearméen i 1960'erne og 1970'erne op til krisen. Perioden har 
stødningsproblemet«, d.v.s. reducere det antal personer, som forlader arbejdsstyrken på grund af nedslidning, sygdom, mangel på relevante kvalifikationer, o.s.v. Hertil krceves et højt understøttelsesniveau. Under krisen, hvor kapitalens akkumulationsskranke ikke længere er arbejderbefolkningens absolutte størrelse, men dens pris, er der ikke behov for at vedligeholde reservearméen i samme omfang som hidtil. Understøttelsesniveauet kan af den grund uden videre nedsættes. Samtidig er lavere understøttelsesniveau med til at løse det såkaldte »paradoks-problem «, som består i, at der angiveligt skulle være mangel på arbejdskraft (arbejdskraft kan ikke anvises, hævdes det) samtidig med stor arbejdsløshed. Paradoks-problemet består dog ret beset ikke i andet end beklagelser over, at de materielle betingelser for løntryk ikke umiddelbart er tilstede.

Der er næppe tvivl om, at sænkningen af arbejdsløshedsunderstøttelsen vil blive fulgt op af yderligere sænkninger og af ændringer i de dele af socialog arbejdsmarkedspolitikken, som under den intensive akkumulationsfase var knyttet til vedligeholdelse af reservearméen gennem statsapparatets reproduktive foranstaltninger. Det vil skærpe konkurrencen mellem arbejderklassens beskæftigede og ubeskæftigede del og åbne for løntryk, som hurtigt vil kunne forplante sig til hele arbejderklassens lønniveau.

\section{Afsluttende bemærkninger}

Vi har i artiklen forsøgt at påvise de rammer, som den borgerlige stat fungerer under. Statsapparatets $\varnothing$ konomiske grundlag er ubønhørligt knyttet til den kapitalistiske produktion; statens eksistens forudsætter udbytningen og dens funktioner er knyttet til udbytningsforholdenes reproduktion.

På dette grundlag har vi opstillet de logiske muligheder for statslig krisepolitik - ikke for at forbedre - men for at påvise det strukturerende indhold i den statslige krisepolitik. Tilsyneladende handler krisepolitikken fra krisegennemslag til i dag om det samme: reallønsnedgang og besparelser. Vi har forsøgt at vise, at der faktisk er forskelligheder og udviklingstendenser i krisepolitikken. Den begynder med den indbyrdes front mellem stat og kapital, som fører til en konfrontation med arbejderklassens stærkeste del - den beskæftigede del - som har strejkevåbnet, og som ikke giver efter. Krisepolitikken er på det

dog også været præget af fors $\emptyset \mathrm{g}$ på at udvide arbejdsstyrken ved at inddrage kvinderne på arbejdsmarkedet, som især har sat fokus på børneinstitutionspolitikken og lavtlønsproblemerne gennem såkaldt solidarisk lønpolitik og ligeløn. 
seneste under forvandling til en politik, som handler om stat og kapitals fælles front mod arbejderklassen, som har ført og tydeligvis yderligere vil føre til angreb på arbejderklassens svageste del: den ubeskæftigede del, den del, hvis reproduktionsvilkår suverænt fastsættes af staten.

Den første krisepolitik faldt sammen. Det viste sig - som sagt mange gange $f \varnothing r-$ at forligene og krisepolitikken ikke bliver afgjort på Christiansborg, men på arbejdspladserne. Der er intet, som forhindrer, at erfaringerne fra den første krisepolitik bliver historien om den anden; men det er en noget større opgave.

I denne sammenhæng er det vigtigt at præcisere, hvad vi har undersøgt, og hvad vi ikke har undersøgt. Gennem undersøgelserne har vi forsøgt at fastlaegge den statslige krisepolitiks begreb; det fører nødvendigvis til ensidigheder eller abstraktioner fra historiske omstændigheder, som er vigtige i en samlet forståelse af krisens udvikling og konsekvenser for arbejderklassen og arbejderklassens modaktioner. Vi har således ikke nærmere inddraget hverken kapitalens bevægelser og krisereaktioner eller arbejderklassens politiske udvikling under kriseforløbet. Det er omstændigheder, som må inddrages, hvis denne undersøgelse af den statslige krisepolitiks begreb skal omsættes til angivelse af konkrete handlemuligheder.

Vi har vist, at det centrale indhold i den statslige krisepolitik - for ikke at sige det eneste strukturerende indhold - er fors $\emptyset \mathrm{g}$ på at påvirke udbytningsforholdene og udbytningsresultatets fordeling mellem stat og kapital. Krisepolitikkens omdrejningspunkt er den produktive arbejder, men dens virkninger forgrener sig til alle dele af arbejderklassen. ${ }^{34}$

34. Vi har tidligere nævnt, at statsapparatet som en dominerende arbejdsgiver har mulighed for at påvirke den produktive lønarbejders reallønsudvikling gennem underbetaling af de statslige lønarbejdere. En sådan politik har været gennemført, som vi kort skal vise. Den statslige (amtslige og kommunale) lønarbejders løn reguleres gennem overenskomst, pristalsregulering og taktregulering, hvor taktreguleringen skal kompensere for den lønglidningsmulighed, som de statslige lønarbejdere ikke har. Alle dele fastsættes imidlertid centralt; i sin lønpolitik er staten derfor ikke direkte afhængig af de lokale forhold, men kan i princippet suverænt fastsætte lønvilkårene; i krisen har det centrale spørgsmål været forhandlinger om taktreguleringen; resultaterne af disse forhandlinger er blevet en reallønsnedgang for de statslige lønarbejdere, hvad følgende eksempel kan vise: et postbud på slutløn fik i 1975 en løn, svarende til 91\% af en mandlig arbejder; i 1979 udgjorde den kun 84\%; et postbud på begyndelsesløn fik i $197578 \%$ af en mandlig arbejder; i 1979 var det reduceret til 74\%. Hvis lønnen skal op på samme niveau som i 1975 forudsætter det en procentvis stigning på $8 \%$ for postbudet på slutløn og 6\% for postbudet på begyndelsesløn; jvf. AC-debat, nr. 6, juni 1980, s. 91. Det kan være vanskeligt at afgøre om den statslige underbetalingspolitik har haft direkte virkninger på reallønsudviklingen for den produktive arbejder, omend det var den erklærede hensigt $\mathrm{i}$ Septemberforliget 1975. Men det har betydet relative besparelser på statsapparatets udgifter til køb af arbejdskraft. 
Den statslige krisepolitik består imidlertid af mere end det. Alle statslige funktionsområder og de politikfelter, der er knyttet til dem, undergår eller vil uden tvivl undergå forandringer eller blive forsøgt reformeret i en retning, som modsvarer det strukturerende indhold i den nuværende statslige krisepolitik. 